\title{
The Middle Miocene freshwater mollusk fauna of Lake Gacko (SE Bosnia and Herzegovina): taxonomic revision and paleoenvironmental analysis
}

\author{
Thomas A. Neubauer*, Oleg Mandic and Mathias Harzhauser \\ Department of Geology \& Paleontology, The Natural History Museum Vienna, Burgring 7, 1010 Wien, Austria. \\ E-mails: thomas.neubauer@nhm-wien.ac.at; oleg.mandic@nhm-wien.ac.at; mathias.harzhauser@nhm-wien.ac.at
}

Received 9 March 2012

Accepted 24 September 2012

Published 20 February 2013

\begin{abstract}
The early Middle Miocene Lake Gacko was part of the Dinaride Lake System (DLS) and gave rise to a poorly known freshwater mollusk fauna. This was subject to malacological studies from the late 19th century onwards. Herein, we provide the first thorough taxonomic survey of Lake Gacko including revisions of several taxa. A total amount of 1,077 specimens was obtained from 17 samples, comprising at least 11 freshwater and 2 terrestrial gastropod species and 6 bivalve species. So far, none of the described taxa has been documented outside the Dinarides and the DLS, respectively. The fauna shows variable overlap with other paleolakes of the DLS, proofing once more the complex biogeographic patchwork of this system. The current paleoenvironmental reconstructions are tested and refined by application of a statistical analysis. This confirms the partition of the sedimentary history of Lake Gacko into three major depositional phases responding to astronomically forced climate changes. The low diverse mollusk assemblage in the initial phase, with abundant pulmonate and rissooid gastropods, signals a more arid climate with lowered lake level. During the second interval, the fauna becomes more diverse with common rissooid and melanopsid gastropods. It represents a more humid interval with enhanced precipitation and increased lake level, entailing the installation of a perennial lacustrine environment. The final phase is a return to arid conditions with the same elements as in the initial pulmonaterissooid assemblage. The sphaeriid Pisidium vukovici n. sp. is introduced as new species.
\end{abstract}

Additional supporting information may be found in the online version of this article at the publisher's web-site

\section{Introduction}

During the Early to Middle Miocene the Dinaride mountain chain harbored a series of intramontane lakes, collectively termed the Dinaride Lake System (DLS; Figs 1A-B; Krstić et al. 2003; Harzhauser \& Mandic 2008). These tectonically isolated lakes experienced an outstanding endemic evolution of freshwater mollusks. Harzhauser \& Mandic $(2008,2010)$ described the DLS fauna as entity and counted 110 gastropod and 35 bivalve species. New investigations by Mandic et al. $(2009,2011)$ and De Leeuw et al. $(2010,2011)$ suggest that the various basins of the DLS have to be considered as separate units with different geodynamic, stratigraphic, and paleoenvironmental histories. Conse- quently, new analyses of the various mollusk assemblages revealed major differences between single basin faunas (Neubauer et al. 2011, 2012). Only during short phases hydrological connection between selected basins might have persisted to allow temporary faunal exchange. This combination of enduring isolation driving endemic evolution and short-term invasions lead to complex distribution patterns and extensive diversifications, which are hard to decipher in taxonomic terms.

Neumayr (1880) and Brusina (1897) provided the first taxonomic papers on the mollusk fauna of the Gacko Basin. These authors partly provided descriptions and illustrations of few taxa, but never established a concise taxonomic frame of the whole basin fauna. Milojević (1966) distinguished between several mollusk

\footnotetext{
* Corresponding author
} 

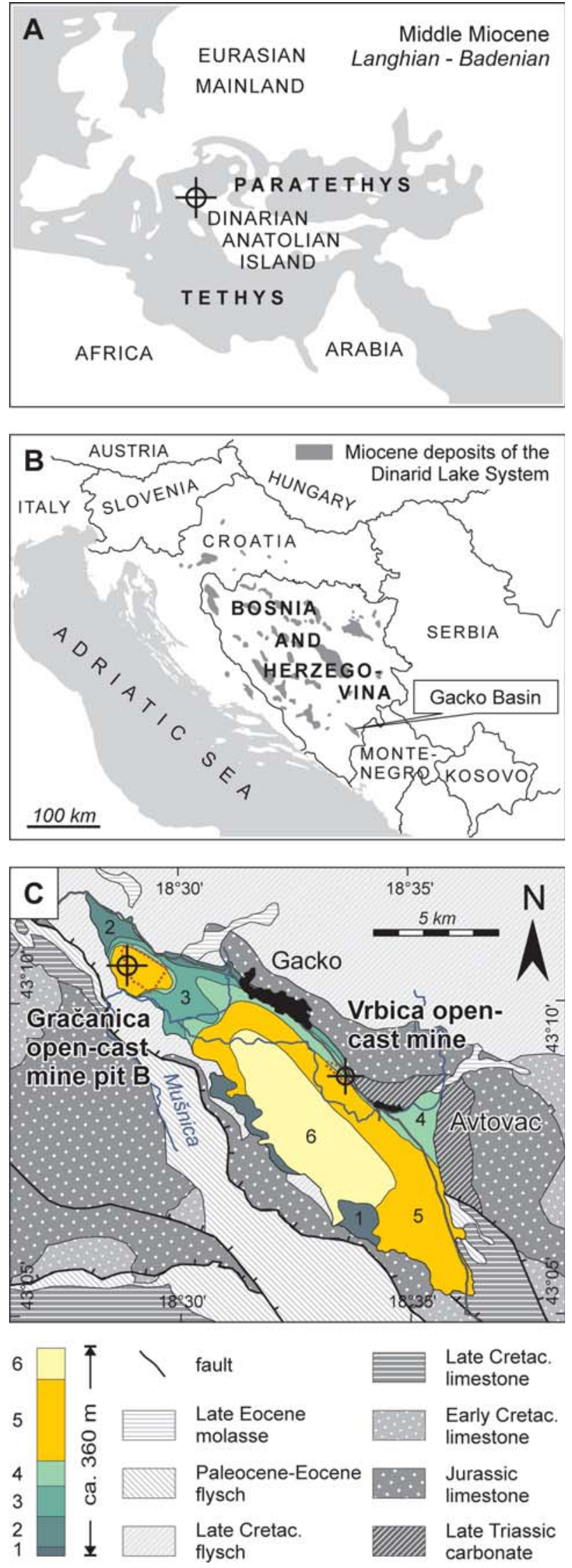

units based on rough faunal differences. Krstić et al. (2009) compiled a faunal synopsis for the lower parts of the basin infill based on drill cores. However, a com-
Figure 1. Geography and geological setting of the studied localities in the Gacko Basin. A. Paleogeographical map of the Dinaride-Anatolian Island during the Langhian (after Rögl 1998 and Harzhauser \& Piller 2007); B. Distribution of DLS deposits and geographic position of Lake Gacko; C. Geological map of the Gacko Basin with indication of the studied sections Gračanica and Vrbica. Numbers and column refer to the general lithostratigraphic division of the Miocene deposits in the Gacko Basin as established by Milojević (1966, 1976) and Mandic et al. (2011).

plete survey of the fauna from Lake Gacko with taxonomic descriptions is still completely missing. Mandic et al. (2011) briefly documented the mollusk distribution and provided a first paleoecological interpretation. By integration of more samples and by application of a statistical analysis these results will be herein tested and modified.

\section{Geological setting}

During the Middle Miocene, the Dinaride-Anatolian Island acted as a major paleogeographic barrier between the Paratethys and the proto-Mediterranean seas (Fig. 1A). The western part of that land mass comprised a large-scale freshwater lacustrine environment, termed the Dinaride Lake System. Today, its deposits represent sedimentary infills of numerous intramontane basins distributed throughout the Dinaride Alps and attaining thicknesses of more than $2000 \mathrm{~m}$ (Hrvatović 2006; Fig. 1B).

The Gacko Basin in southern Bosnia and Herzegovina represents one of those basins (Mojićević \& Laušević 1965; Mirković et al. 1974; Fig. 1C). The architecture of its about 360 meters thick sedimentary succession can be interpreted as a single lacustrine transgression-regression mega-cycle (Milojević 1966, 1976; Mandic et al. 2011). The sedimentation started with detrital deposits representing the initial flooding of the basin. The subsequent coal building phase marks the installation of swamp conditions, passing upwards into limestones originating from hard-water freshwater lake deposition. Subsequently, dropping water levels triggered again swamp and mire conditions in the terminal phase of Lake Gacko.

Basin history and depositional setting have been currently studied at Gračanica WNW of Gacko by Mandic et al. (2011). Additionally, a small outcrop ( $\sim 1$ m thickness) was included from the abandoned Vrbica opencast coal-mine NW of Avtovac, representing the boundary interval of the uppermost main coal unit and the lowermost Mytilopsis unit, respectively (Figs 1C, 2). The huge outcrop at the Gračanica opencast coal-mine provided an excellent insight into the lake deposition on the basin's paleo-margin. Results from integrated $\mathrm{Ar} / \mathrm{Ar}$ geochronology and magnetostratigraphy fixed the age of the lacustrine deposition into the Langhian, implying its relation with the Middle Miocene Climatic 


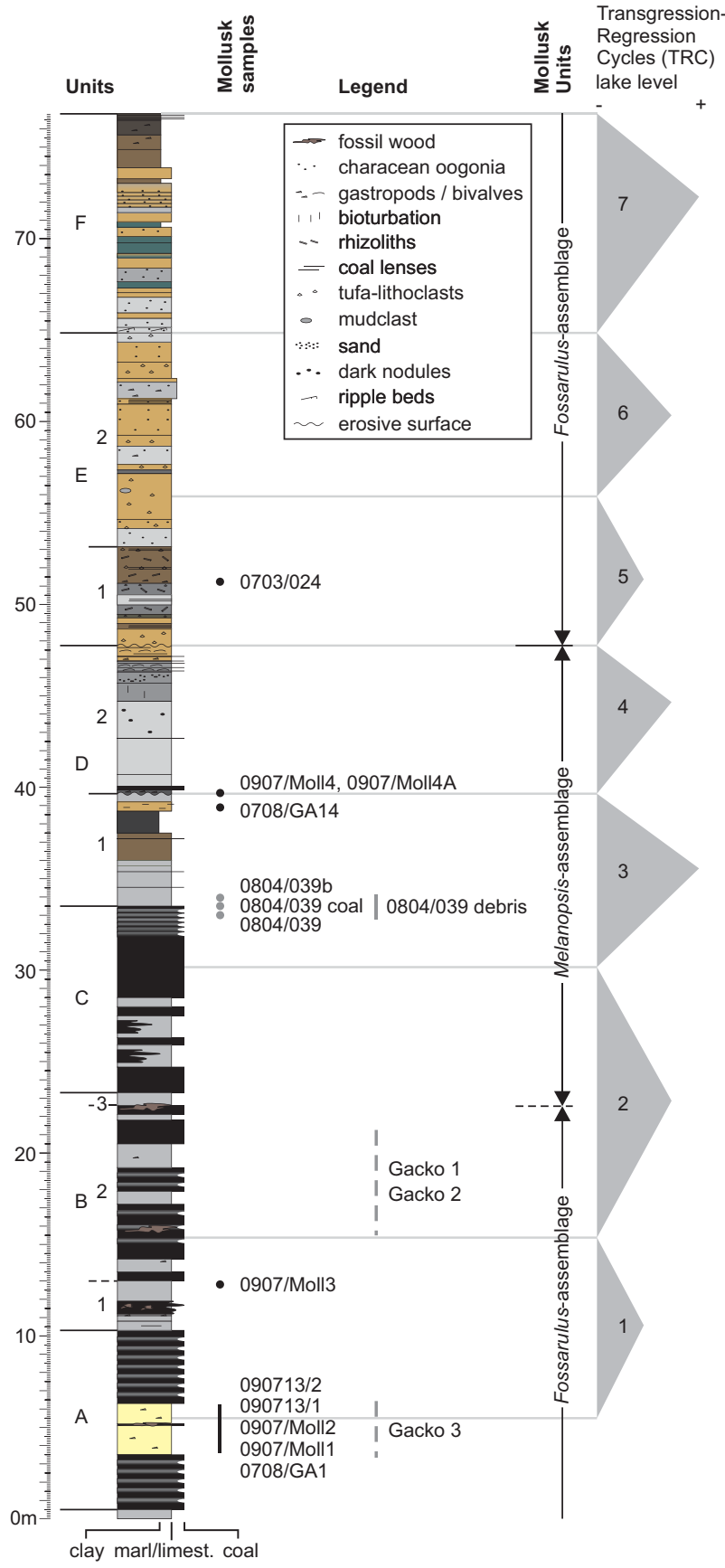

Figure 2. Section Gračanica, mine pit B with position of the mollusk samples. Those correlated from the Vrbica section and drill cores are colored in gray. Bars indicate non-stratified, unit-related samples; dashed bars indicate uncertain correlation of samples from drill cores (modified after Mandic et al. 2011).

Optimum (Mandic et al. 2011). Furthermore, results from sediment petrography, geophysical logging and mollusk paleoecology indicated vivid changes of the regional water budget (Mandic et al. 2011). Indeed, the cyclostratigraphic analysis revealed the presence of two first order and seven second order transgression-regression cycles (Fig. 2, right column). These were orbitally tuned to $\sim 400 \mathrm{kyr}$ and $\sim 100 \mathrm{kyr}$ eccentricity cycles resulting in an accurate age model for its depositional duration from $\sim 15.8$ to $\sim 15.2 \mathrm{Ma}$. The lake level high- stands were thereby related to eccentricity maxima, accompanied by environmental eutrophication events in consequence to enhanced denudation and terrestrial input into the basin. Dry climate intervals were related to $\sim 400 \mathrm{kyr}$ eccentricity minima. In the lower part of the succession they resulted in iterative swamp forest extension reflected by vast lignite accumulations. In the upper part they formed pedogenic and palustrine carbonate accumulations, distributed across the basin's margin.

\section{Material and methods}

For this study 17 samples from three different sites were investigated: 10 from the Gračanica mine, 4 from the Vrbica section, and 3 from drill cores (near Gacko, exact locality unknown; provided by S. Ćorić, Geological Survey Vienna, and stored in the collection of the NHMW) (Fig. 1C). The samples were dissolved with diluted hydrogen peroxide and washed through a set of sieves $(1 \mathrm{~mm}, 250 \mu \mathrm{m}, 125 \mu \mathrm{m}$, $63 \mu \mathrm{m})$. Mollusks were counted from the $1 \mathrm{~mm}$ fraction only, yielding a total individual number of 1,077 specimens. In addition, a high number of specimens was obtained from smaller fractions comprising mostly juvenile stages and spire fragments. In most cases, these could not be determined on the species level. As some taxa (e.g. planorbids, lymnaeids) are prone to fragmentation because of their thin shell walls, they might be underrepresented in the larger fractions. Some taxa are exclusively found in smaller fractions $(<1 \mathrm{~mm})$ or in debris collections and thus do not appear in the quantified record (Fig. 3).

The statistical analysis was compiled using Primer 6.1 .10 (Clarke $\&$ Warwick 2001). The data set with percentage values was square root transformed to limit the contribution of over-represented taxa. Based on the Bray-Curtis distance measure an average group cluster analysis (Fig. 4A) and a non-metric multidimensional scaling (nMDS; Fig. 4B) with minimum stress of 0.01 were generated. For the resulting groups factors were defined for a Simper analysis (Tab. 1) to outline which taxa were contributing to similarities and dissimilarities, respectively. Diversity indices were calculated using Past 2.06 (Hammer et al. 2001). Samples with $\leq 25$ individuals or those from debris collections or drill cores (imprecise stratigraphic correlation) were excluded.

\section{Faunal composition and paleobiogeography}

The investigation yielded a total of 13 gastropod (13 genera) and 6 bivalve species (3 genera). These are Melanopsis lyrata Neumayr, 1869 (Fig. 5), Bithynia jurinaci Brusina, 1884 (Fig. 6), Fossarulus moniliferus Brusina, 1876 (Fig. 6), Prososthenia neutra Brusina, 1897 (Fig. 7), Bania valvatoides (Brusina, 1874) (Fig. 8), Galba sp. (Fig. 9), Radix korlevici (Brusina, 1884) (Fig. 9), Gyraulus pulici (Brusina, 1897) (Fig. 10), Orygoceras dentaliforme Brusina, 1882 (Fig. 10), Planorbarius sp. (Fig. 11), Ferrissia illyrica (Neumayr, 1880) (Fig. 11), Carychium sp. (Fig. 12), Vertigo sp. (Fig. 12), Mytilopsis frici (Brusina, 1904) (Fig. 13), Mytilopsis jadrovi (Brusina, 1892) (Fig. 14), Mytilopsis sp. (Fig. 14), Pisidium bellardii Brusina, 1884 (Fig. 14), Pisidium vukovici n. sp. (Fig. 14), Unio rackianus Brusina, 1874 (Fig. 15). Two further species 


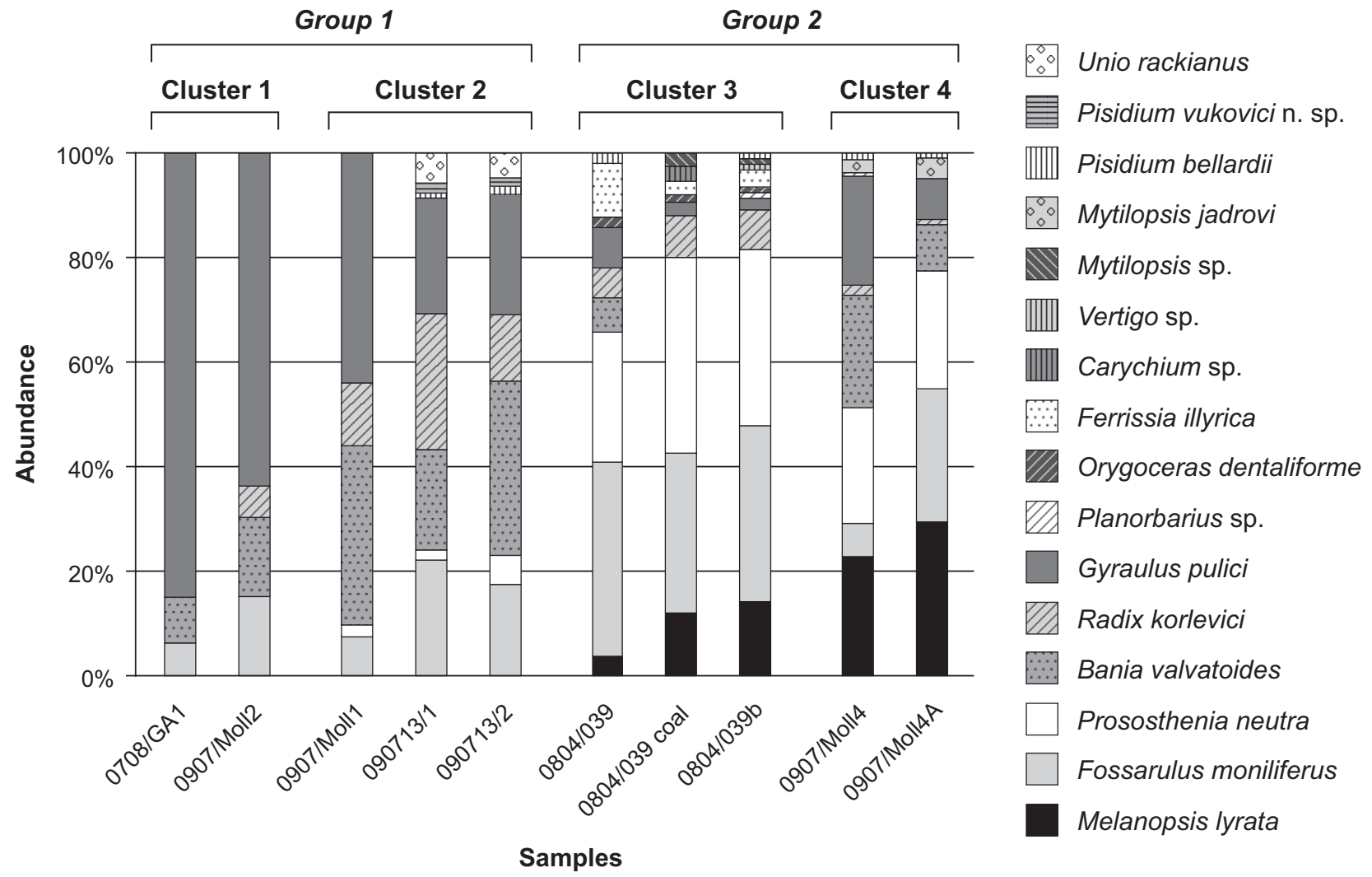

Figure 3. Abundance data of mollusk taxa with indications of groups and clusters resulting from the statistical analysis.

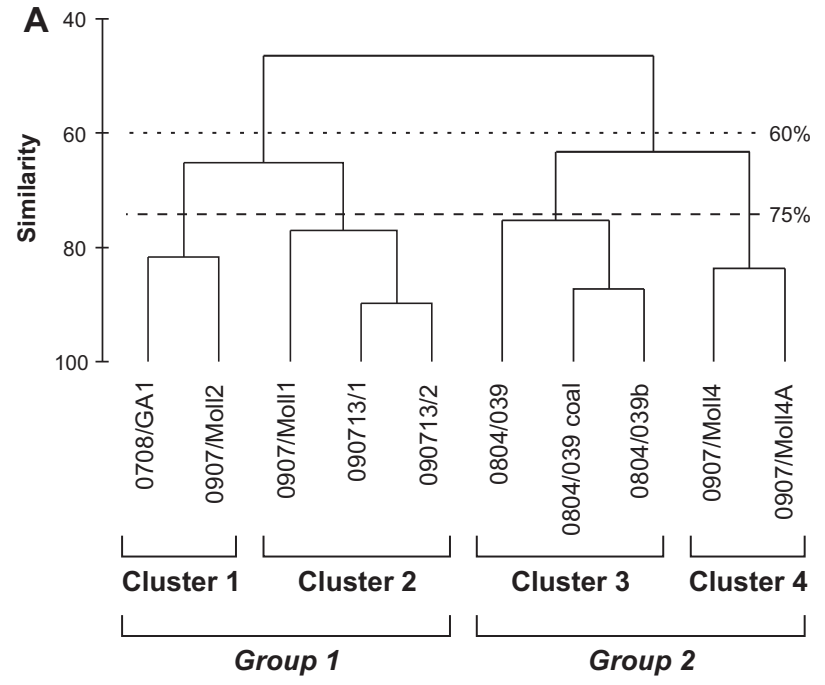

B

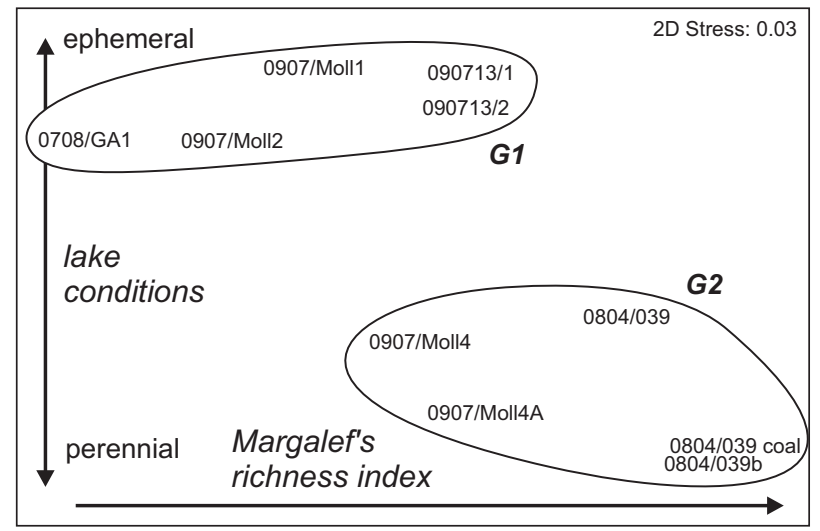

recorded for the Gacko Basin, i.e. Stalioa parvula Neumayr, 1880 and Euchilus elongatus Neumayr, 1880, could not be detected in the course of this investigation. All taxonomic descriptions, except that for the new species, are provided as supplementary material.

All recorded freshwater taxa that were determined on species level are endemic to the Dinaride Lake System. Nevertheless, there are notable differences concerning the distribution of the various taxa within the lake system. Distinct faunistic relationships of the Gacko Basin fauna on the species level are evident for the Drniš Basin $(57.9 \%)$ and the Sinj Basin (52.6\%). In contrast, the roughly equally distanced Kupres Basin shares only a single taxon accounting for $5.3 \%$ similarity (Orygoceras dentaliforme). However, notable faunal overlaps are known between the Sinj/Drniš basins and the Kupres Basin (39\%; Neubauer et al. 2012), which are geographically closer to each other than to the Gacko Basin. The stratigraphic age of the considered deposits is comparable, ranging around 15.8 to $15.0 \mathrm{Ma}$ (Neubauer et al. 2012). Most probable, faunal exchange was performed via hydrological connections, which existed to the Sinj and Drniš basins but not (or only for short episodes) to the Kupres Basin. These connections are

Figure 4. Statistical analysis of quantified samples using BrayCurtis distances of square root transformed data. A. Cluster analysis (group average); B. Non-metric multidimensional scaling (minimum stress of 0.01). 

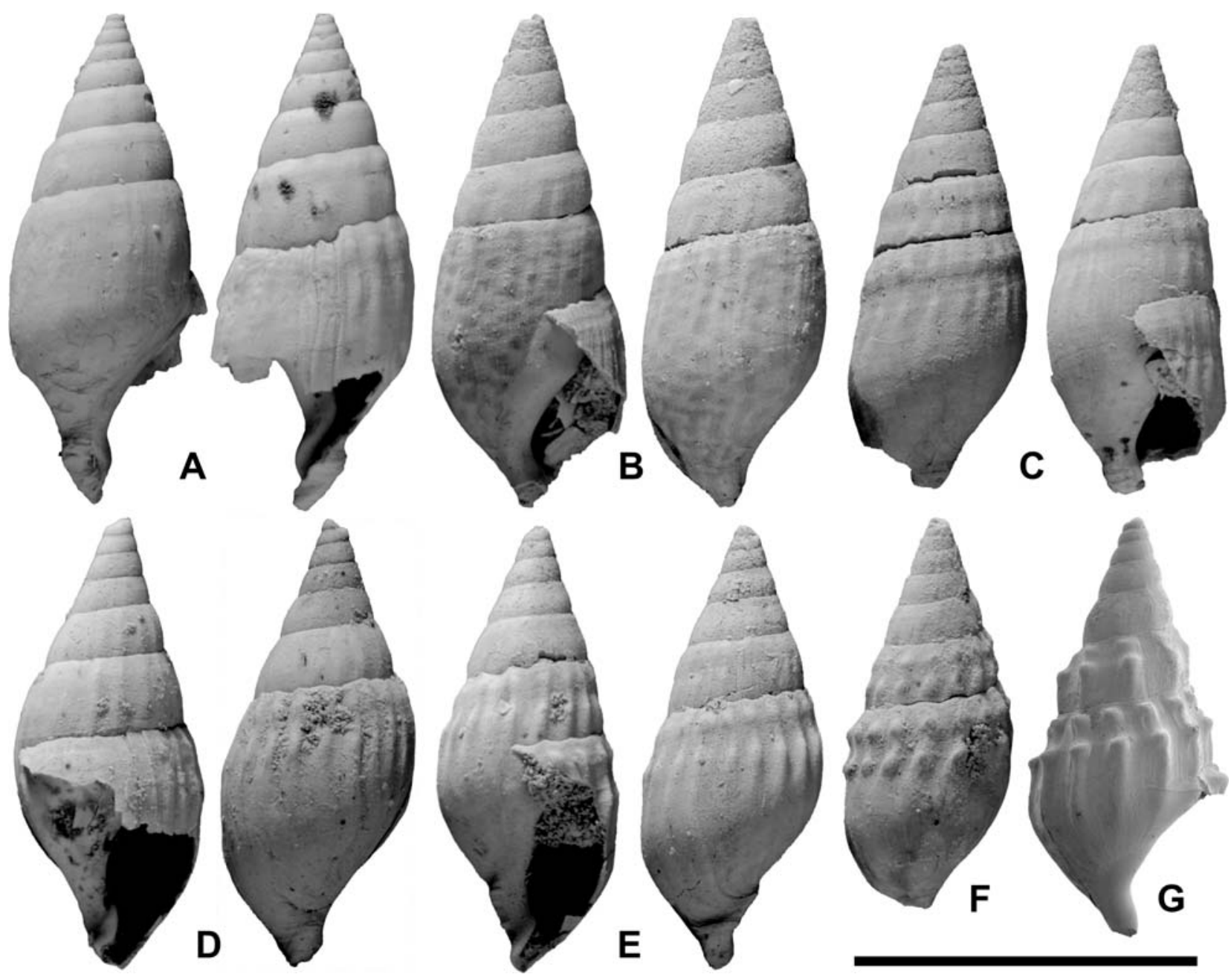

Figure 5. Morphotypes of Melanopsis lyrata Neumayr, 1869. A. NHMW 2011/0138/0129, sample 0804/039 debris, morphotype B; B. NHMW 2011/0138/0130, sample 0907/Moll4A, morphotype B; C. NHMW 2011/0138/0131, sample 0907/Moll4A, morphotype C; D. NHMW 2011/0138/0132, sample 0907/Moll4A, morphotype C; E. NHMW 2011/0138/0133, sample 0907/Moll4A, morphotype D; F. NHMW 2011/0138/0134, sample 0907/Moll4A, morphotype E; G. NHMW 2011/0138/0135, sample 0804/039 debris, morphotype E. Scale bar equals $1 \mathrm{~cm}$.

likely to have occurred during the several transgression maxima in the history of the Gacko Basin (Mandic et al. 2011). This is emphasized by the appearance of several taxa only within certain units (e.g. Bithynia jurinaci, Orygoceras dentaliforme, Mytilopsis jadrovi, Unio rackianus). However, a unit-related trend, meaning higher percentages of invaders in specific intervals, could not be detected.

\section{Results of the statistical analysis}

The distribution of samples within the succession is heterogeneous. The statistically analyzable samples were confined to three section intervals: $3.5-6.0 \mathrm{~m}$ (Unit A; 5 samples), 33.0-34.0 m (transition between units $\mathrm{C} / \mathrm{D} 1 ; 3$ samples), and $39.5 \mathrm{~m}$ (transition between units D1/D2; 2 samples). In between, only few samples were taken because of the generally poor preservation. Samples were either too small for a significant quantification or were collected from debris.
The stratigraphic grouping of the samples is reflected in the faunal contents as proven by the statistical analysis (Figs 3, 4). The cluster analysis shows two main groupings at a similarity level of $60 \%$, which correspond to the two lower intervals termed as Fossarulusand Melanopsis-assemblages in Milojević (1966) and Mandic et al. (2011). Group 1, with $71.7 \%$ average similarity, is dominated by Gyraulus pulici, followed by Bania valvatoides and Fossarulus moniliferus. Group 2 is largely defined by Prososthenia neutra, Fossarulus moniliferus and Melanopsis lyrata, with an average similarity of $70.1 \%$ (Tab. 1). These obvious faunal differences are proven by an average dissimilarity between the two groups of $53.6 \%$.

In more detail, each of the two groups can be split into two clusters as suggested by the cluster analysis (at a $75 \%$-similarity level; Figs 3, 4). Samples from Cluster 1 (Unit A) are clearly dominated by pulmonate and rissooid gastropods (Fig. 3; Tab. 1), namely Gyraulus pulici, Bania valvatoides and Fossarulus moniliferus. This cluster, with an average similarity of $81.7 \%$, is de- 

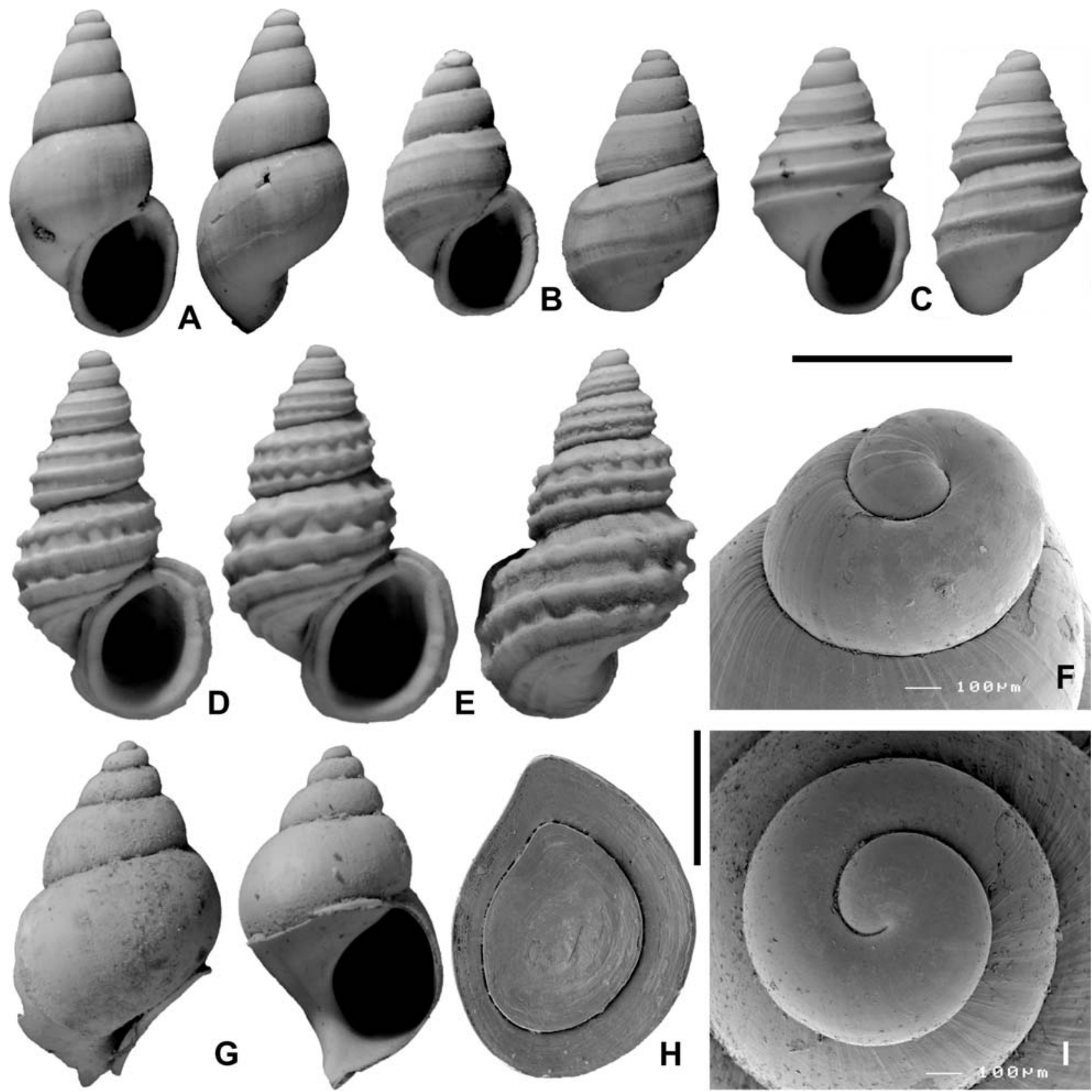

Figure 6. A. Fossarulus moniliferus Brusina, 1876, NHMW 2011/0138/0136, sample 090713/1, morphotype A; B. Fossarulus moniliferus Brusina, 1876, NHMW 2011/0138/0137, sample 090713/1, morphotype A/B; C. Fossarulus moniliferus Brusina, 1876, NHMW 2011/0138/0138, sample 090713/1, morphotype B; D. Fossarulus moniliferus Brusina, 1876, NHMW 2011/0138/0139, sample 0804/039 debris, morphotype C; E. Fossarulus moniliferus Brusina, 1876, NHMW 2011/0138/0140, sample 0804/039 debris, morphotype C; F. Fossarulus moniliferus Brusina, 1876, NHMW 2011/0138/0141, sample 0708/GA1, morphotype A; G. Bithynia jurinaci Brusina, 1884, NHMW 2011/0138/0143, sample 0804/039 debris; H. Bithynia jurinaci Brusina, 1884, NHMW 2011/0138/0144, sample 0708/GA14, operculum; I. Fossarulus moniliferus Brusina, 1876, NHMW 2011/0138/0142, sample $090713 / 2$, morphotype A. Scale bars equal $5 \mathrm{~mm}(\mathrm{~A}-\mathrm{I}, \mathrm{K}-\mathrm{L})$ and $1 \mathrm{~mm}(\mathrm{M})$, respectively.

fined by these 3 taxa only. Cluster 2 (also Unit A), with a comparable average similarity of $81.3 \%$, is defined by Bania valvatoides, Gyraulus pulici, Radix korlevici, Fossarulus moniliferus and Prososthenia neutra, accounting for $92.8 \%$. In addition, Unio rackianus (only record in the section), Pisidium bellardii and P. vukovici n. sp. appear. While the differences between the two groups are distinct, deviations between clusters within the groups are in both cases comparably low. Clusters 1 and 2 show an average dissimilarity of $34.8 \%$, resulting from slightly varied values for Gyraulus pulici, Radix korlevici and Bania valvatoides, and the presence of Prososthenia neutra and Unio rackianus in Cluster 2.

The following 25 meters of limestone-coal interbeddings were inadequate for an analysis. Few findings of Fossarulus moniliferus, Galba sp., Gyraulus pulici and Ferrissia illyrica are reported from sample 0907/Moll3 (Unit B1). This is the only occurrence of the lymnaeid Galba within the whole section. Samples Gacko 1 and Gacko 2 from roughly correlated drill cores (Unit B2; 

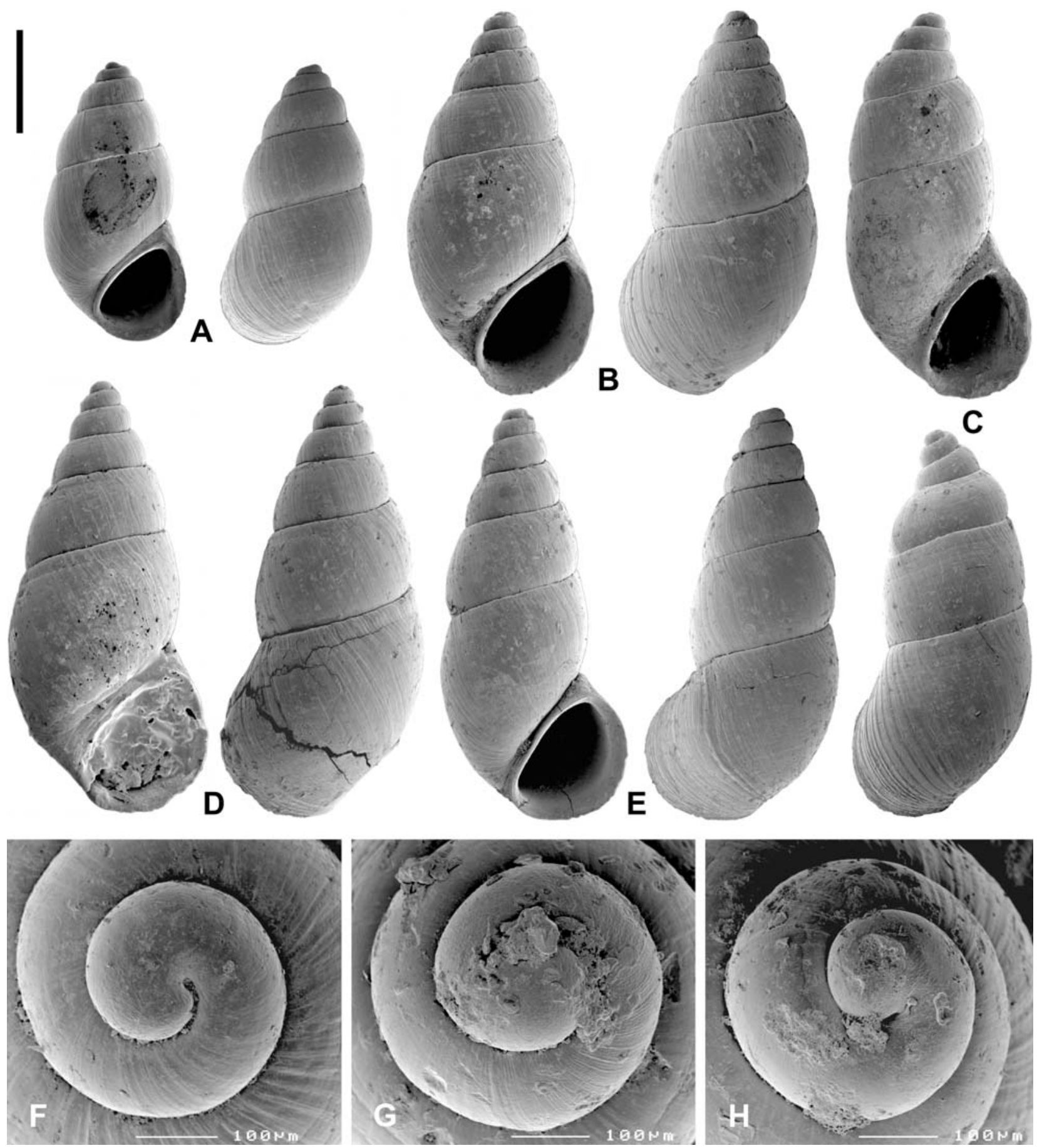

Figure 7. Prososthenia neutra Brusina, 1897. A, F. NHMW 2011/0138/0145, sample 090713/2; B. NHMW 2011/0138/0146, sample 0907/Moll4A; C, H. NHMW 2011/0138/0147, sample 0907/Moll4A, distorted specimen; D, G. NHMW 2011/0138/0148, sample 0907/Moll4A; E. NHMW 2011/0138/0149, sample 0907/Moll4A. Scale bar equals $1 \mathrm{~mm}$.

Fig. 2) provided few remains of Fossarulus moniliferus, Radix korlevici and Gyraulus pulici.

Cluster 3 from the transition of units C/D1 with correlated samples from the Vrbica section yielded three analyzable samples (Fig. 2). This cluster has an average similarity of $79.2 \%$. The most abundant taxa are Fossarulus moniliferus and Prososthenia neutra followed by Radix korlevici, Melanopsis lyrata, Ferrissia illyrica and Gyraulus pulici. These 6 taxa contribute with $91.5 \%$ to the average similarity. Additional taxa are
Bithynia jurinaci (from debris only), the planorbids Planorbarius sp. and Orygoceras dentaliforme, the terrestrial mollusks Carychium sp. and Vertigo sp., and the dreissenid Mytilopsis sp. Sample 0708/GA14 at the top of Unit D1, too small to be analyzed, yielded abundant Bithynia opercula $(68.0 \%)$ and Ferrissia illyrica (28.0\%), followed by Gyraulus pulici $(4.0 \%)$. This composition changes rapidly c. $1 \mathrm{~m}$ above. The transition of units D1/D2 (Cluster 4) with two samples is defined by 6 species accounting for $90.7 \%$ (Melanopsis 

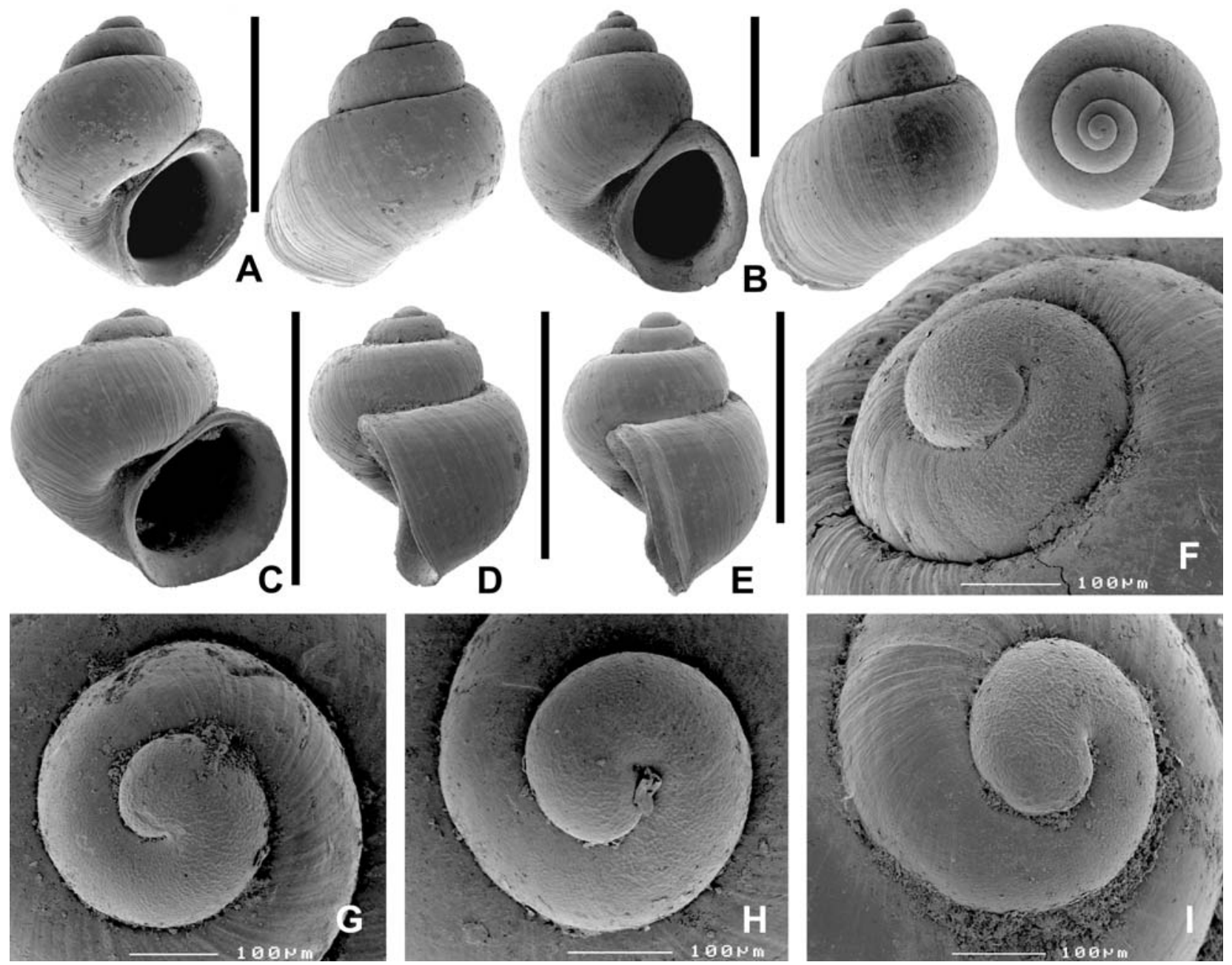

Figure 8. Bania valvatoides (Brusina, 1874). A, G. NHMW 2011/0138/0151, sample 0907/Moll4A; B, H. NHMW 2011/0138/ 0152, sample 090713/2; C. NHMW 2011/0138/0181, sample 090713/2; D. NHMW 2011/0138/0182, sample 090713/2; E, I. NHMW 2011/0138/0183, sample 090713/2; F. NHMW 2011/0138/0153, sample 090713/2. Scale bars equal $1 \mathrm{~mm}$.

lyrata, Prososthenia neutra, Bania valvatoides, Gyraulus pulici, Fossarulus moniliferus and Mytilopsis jadro$v i)$. This is the only occurrence of the dreissenid bivalve Mytilopsis jadrovi. The unity of both samples is confirmed in the analysis by $83.6 \%$ average similarity. Reduced dissimilarity between clusters 3 and 4 $(36.8 \%)$ is rooted in similar abundance values for Fossarulus moniliferus and Melanopsis lyrata. The main differences concern the presence of Ferrissia illyrica in Cluster 3 and higher percentage value of Bania valvatoides in Cluster 4. Interestingly, the dissimilarity levels between clusters 1 and $4(51.0 \%)$ and 2 and 4 $(42.0 \%)$, respectively, is lower than that between clusters 1 and $3(66.6 \%)$ and 2 and $3(53.8 \%)$. In both cases, this can be explained by the recurrence especially of Gyraulus pulici and Bania valvatoides in Cluster 4. The major dissimilarity is based on values for Melanopsis lyrata and Prososthenia neutra, which are less common or absent in clusters 1 and 2.

The top of Unit D2 is marked by monospecific accumulations of Mytilopsis frici (Brusina, 1904) (Mandic et al. 2011). The last sample from Unit E1 did not provide enough material for the analysis. It contains few individuals of Fossarulus moniliferus, Bania valvatoides, Radix korlevici and Planorbarius sp. Upsection (units E2 and F), fossils are poorly preserved, mostly as molds. Mollusk diversity is comparatively low; all detected specimens belong to Fossarulus moniliferus and Radix korlevici.

\section{Mollusk paleoecology and paleoenvironment}

This investigation, which provides the first statistical analysis of the mollusk fauna, allows a refinement of the interpretation by Mandic et al. (2011) and Krstić et al. (2009). From the analysis two main groups are evident, referred to as Fossarulus-assemblage and $\mathrm{Mel}$ anopsis-assemblage in literature (Milojević 1966; Mandic et al. 2011; Fig. 2). The third group, again a Fossarulus-assemblage according to Milojević (1966), yielded only few and small samples and does not appear in our analysis. These assemblages, however, are not defined by the frequent occurrence of their eponymous taxa 


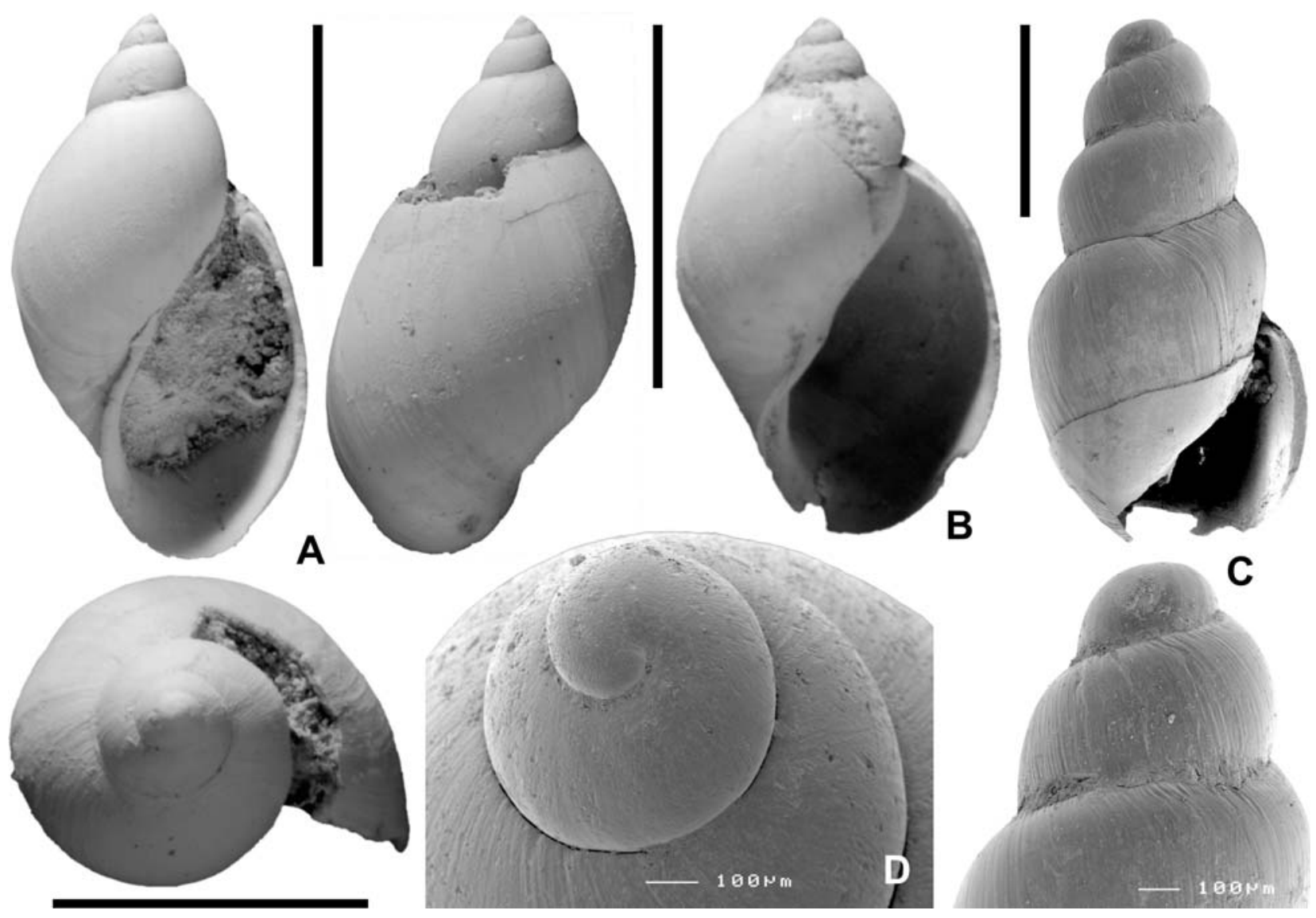

Figure 9. A. Radix korlevici (Brusina, 1884), NHMW 2011/0138/0154, sample 090713/1; B. Radix korlevici (Brusina, 1884), NHMW 2011/0138/0155, sample 090713/1; C. Galba sp., NHMW 2011/0138/0157, sample 0907/Moll3; D. Radix korlevici (Brusina, 1884), NHMW 2011/0138/0156, sample 0804/039 coal. Scale bars equal $5 \mathrm{~mm}$ (A-C, E) and $1 \mathrm{~mm}$ (D), respectively.
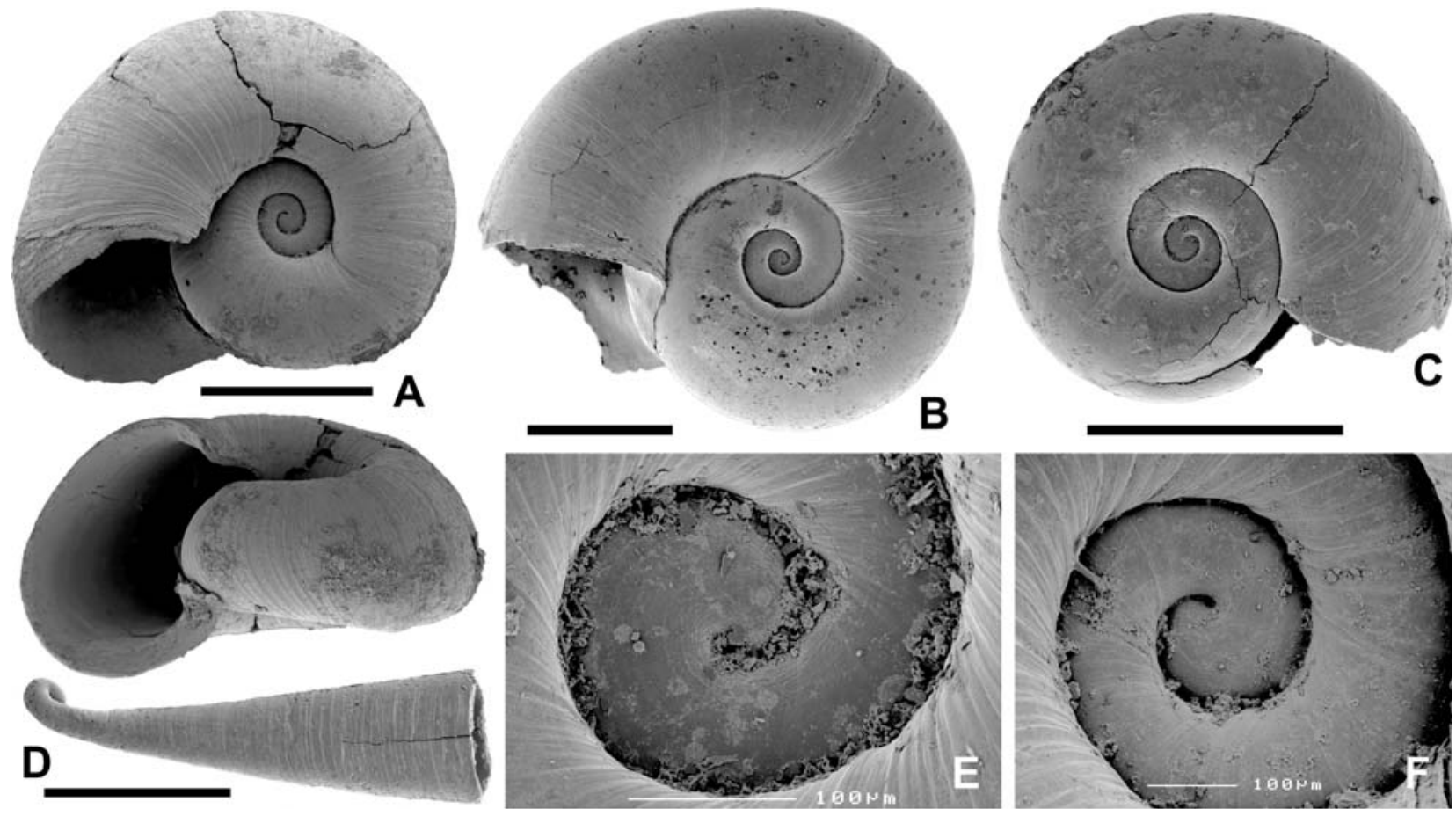

Figure 10. A, F. Gyraulus pulici (Brusina, 1897), NHMW 2011/0138/0158, sample 0804/039; B, E. Gyraulus pulici (Brusina, 1897), NHMW 2011/0138/0159, sample 090713/2; C. Gyraulus pulici (Brusina, 1897), NHMW 2011/0138/0160, sample 0907/ Moll4A; D. Orygoceras dentaliforme Brusina, 1882, NHMW 2011/0138/0161, sample 0804/039. Scale bars equal $1 \mathrm{~mm}$. 

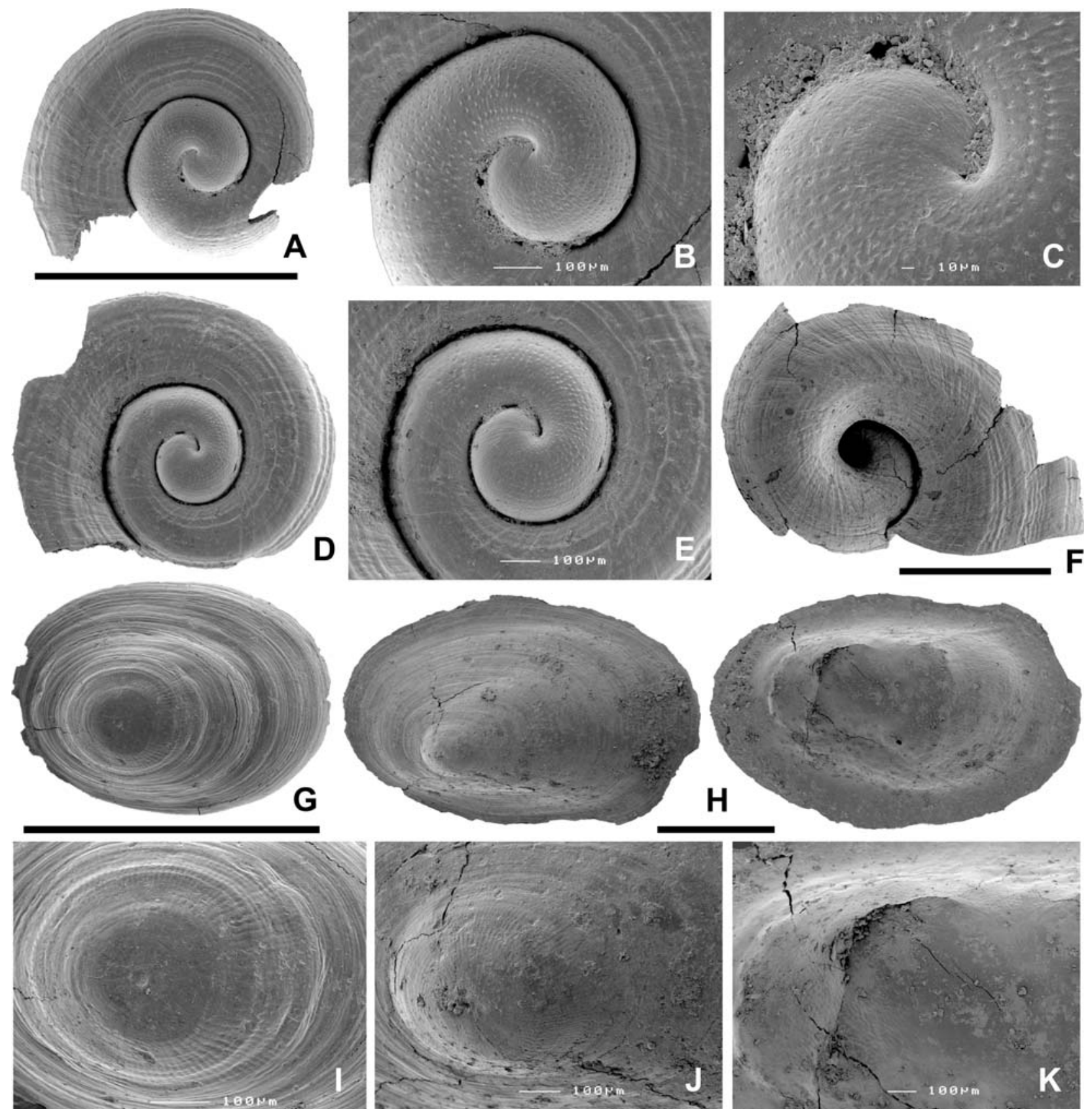

Figure 11. A-C. Planorbarius sp., apical side, NHMW 2011/0138/0163, sample 0804/039 coal; D-E. Planorbarius sp., apical side, NHMW 2011/0138/0164, sample 0804/039b; F. Planorbarius sp., umbilical side, NHMW 2011/0138/0165, sample 0804/ 039b; G, I. Ferrissia illyrica (Neumayr, 1880), NHMW 2011/0138/0166, sample 0804/039b; H, J-K. Ferrissia illyrica (Neumayr, 1880), NHMW 2011/0138/0167, sample 0804/039. Scale bars equal $1 \mathrm{~mm}$.

(Fig. 3; Tab. 1). The Fossarulus-assemblage is dominated by the planorbid Gyraulus pulici, followed by the hydrobiid Bania valvatoides. Likewise, the Melanopsisassemblage is characterized by frequent Prososthenia neutra and Fossarulus moniliferus rather than by Melanopsis lyrata itself. Nevertheless, the grouping into three assemblages remains valid based on the largely deviating faunal compositions (Tab. 1).

The high abundances of the pulmonates Gyraulus and Radix in the first interval (Unit A, clusters 1 and 2) argue for a low-energy shallow water environment with dense vegetation (Glöer 2002). Fossarulus, which appears throughout the whole section, is thought to be a pioneer taxon (Mandic et al. 2011). In Lake Sinj representatives of this fossil genus are found exclusively in rather calm, shallow water settings, dominated by hydrobiids (Neubauer et al. 2011). In Lake Gacko it is, in turn, relatively abundant in nearshore as well as distal environments and thus is regarded to be a euryoecious taxon. The ecology of the fossil genus Bania is completely unknown. As its occurrence is often bound to the presence of Gyraulus, its requirements concerning water quality and vegetation might be comparable. 

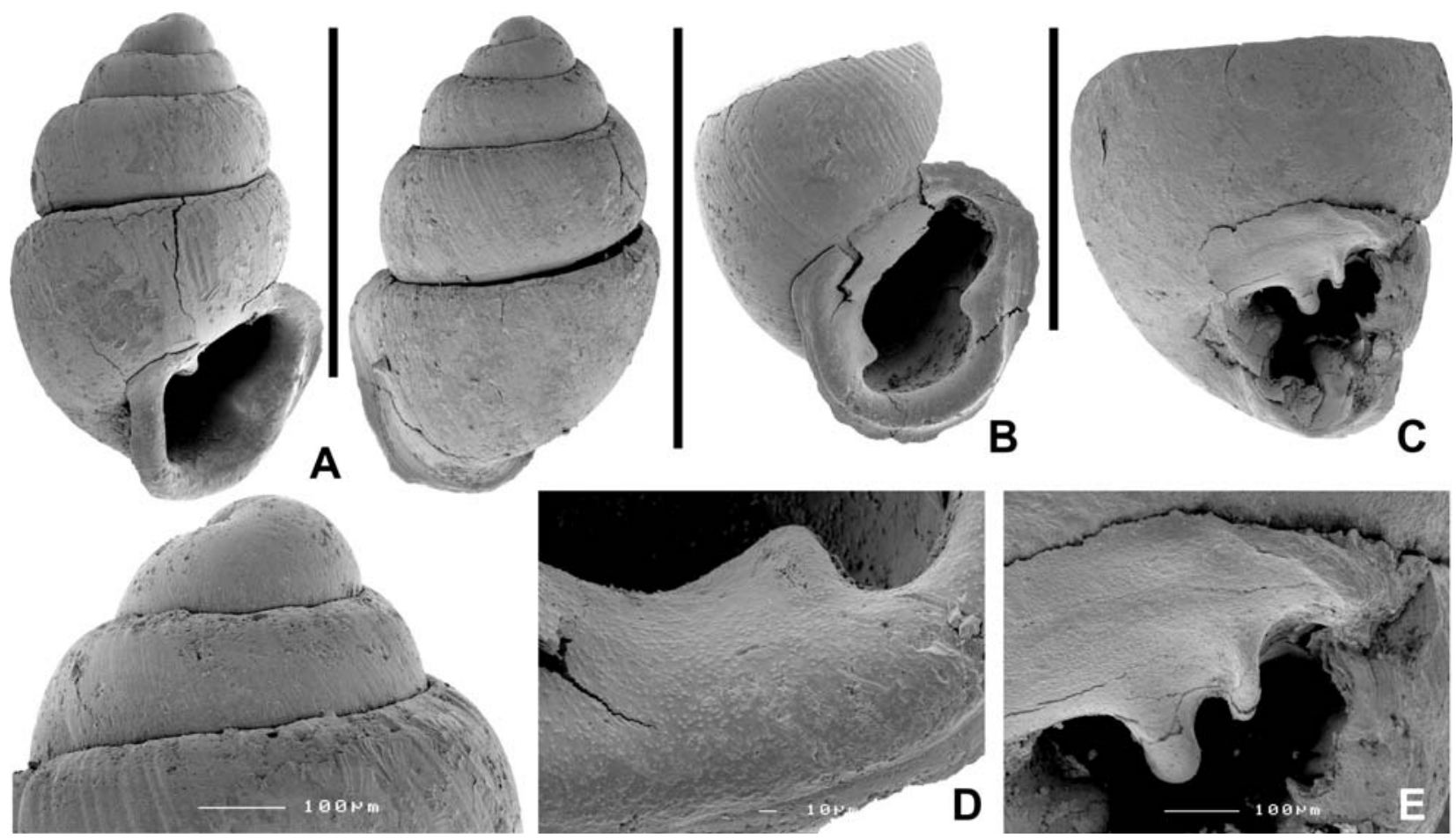

Figure 12. Terrestrial mollusks. A. Carychium sp., NHMW 2011/0138/0168, sample 0804/039; columellar fold not visible in this view; B, D. Carychium sp., NHMW 2011/0138/0169, sample 0804/039 coal; C, E. Vertigo sp., NHMW 2011/0138/0170, sample 0804/039b. Scale bars equal $1 \mathrm{~mm}$.

The dominance of pulmonates indicates that these conditions persisted up to Unit B. Krstić et al. (2009), however, report massive accumulation of Fossarulus within limestone intervals of Unit B1 in drill cores, where this unit attains about $40 \mathrm{~m}$. The corresponding section interval in the Gračanica mine pit measures only $2.5 \mathrm{~m}$ (Mandic et al. 2011). This discrepancy is explained by the highly varying sediment infill in the Gacko Basin, depending on the position in the lake: the marl units in Unit B are massive in the basin center and thin out towards the basin margins (Milojević
1966; Mandic et al. 2011). A better correlation between both sites becomes apparent in the following Unit B2 with abundant pulmonates in both localities.

The second interval (Cluster 3) is marked by the first occurrence of Melanopsis, with smooth to weakly sculptured morphotypes, and the conspicuous increase of Prososthenia and Fossarulus, while pulmonates decline. Species diversity increased significantly with 14 taxa, although most of them are represented by only few individuals. In contrast, 10 species were detected in the first interval.
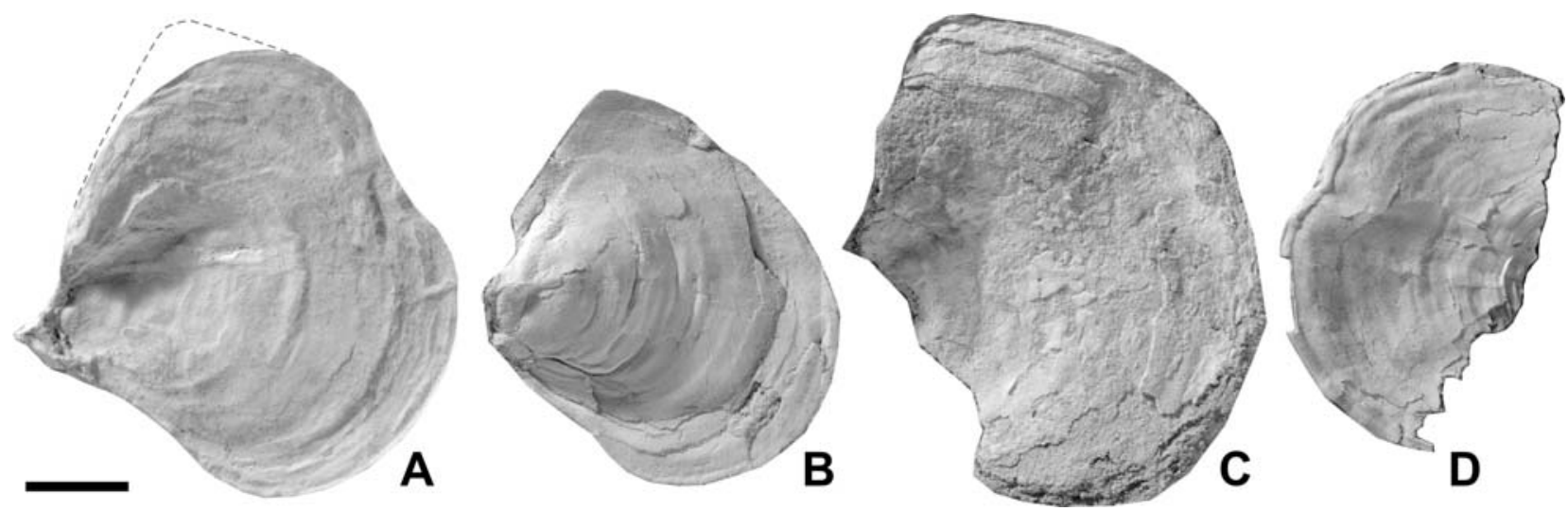

Figure 13. Mytilopsis frici Kochansky-Devidé \& Slišković, 1978. A. RV, interior view, anteriorly most proximal part of exterior LV with transversal ridge preserved, NHMW 2011/0138/0008, Gacko (historical collection); B. Articulated shell, postero-ventral part of RV visible beneath antero-dorsally shifted LV, NHMW 2011/0138/0034, Gračanica Section, Mytilopsis bed (Unit D2); C. Fragment of articulated shell showing flabellate dorsal margin, NHMW 2011/0138/0032, Gračanica Section, Mytilopsis bed (Unit D2); D. Fragment of LV showing thickened margin and posterior sinus (interior view), NHMW 2011/0138/0025, Gračanica Section, Mytilopsis bed (Unit D2). Scale bar equals $1 \mathrm{~cm}$. 

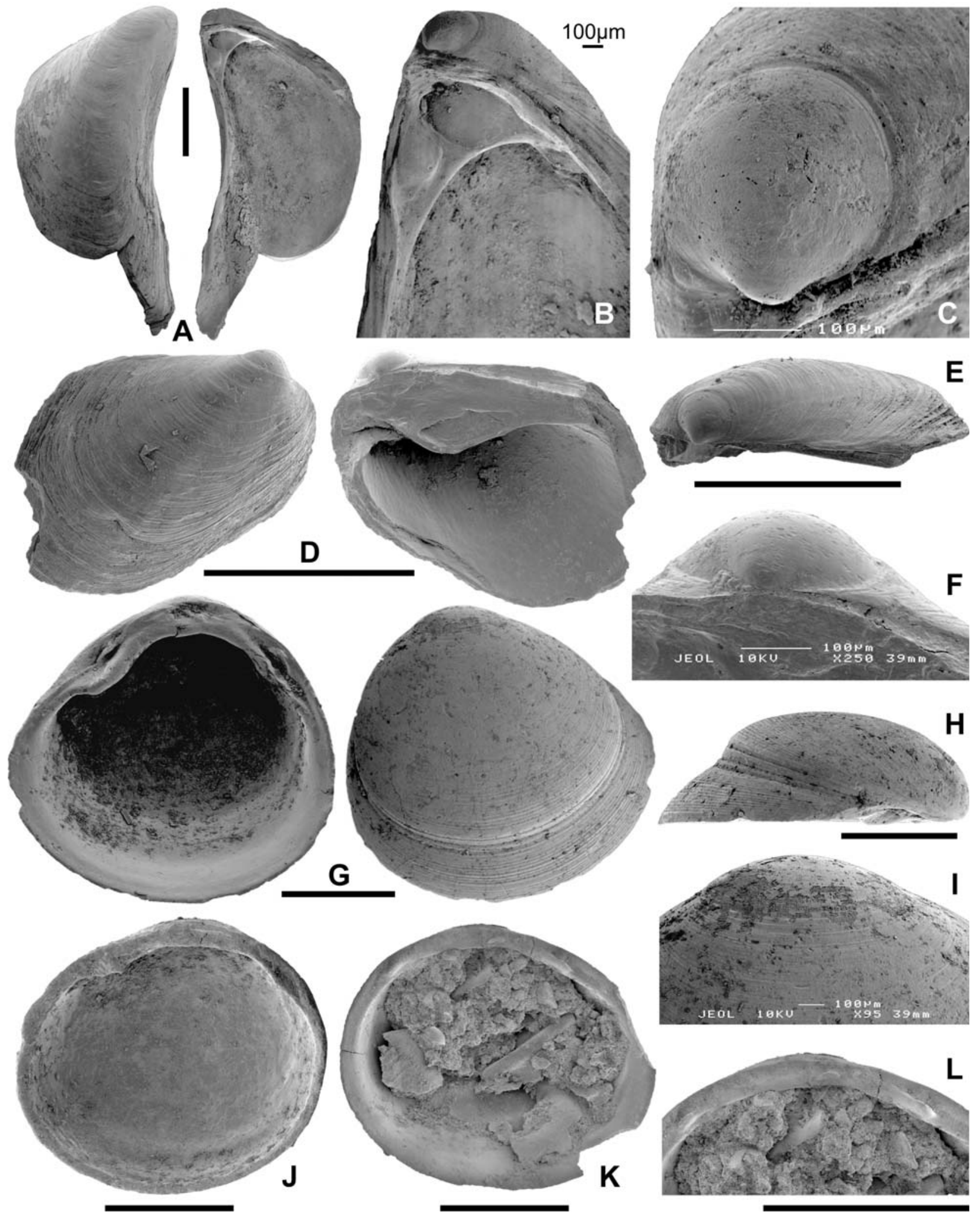

Figure 14. A-C. Mytilopsis jadrovi (Brusina, 1892), NHMW 2011/0138/0171, sample 0907/Moll4A; D-F. Mytilopsis sp., NHMW 2011/0138/0172, sample 0804/039b; G-I. Pisidium vukovici n. sp., holotype, NHMW 2011/0138/0173, RV, sample 090713/2; J. Pisidium bellardii Brusina, 1884, NHMW 2011/0138/0174, RV, sample 0907/Moll4; K-L. Pisidium bellardii Brusina, 1884, NHMW 2011/0138/0175, sample 0907/Moll4, LV. Scale bars equal $1 \mathrm{~mm}$.

Today, Melanopsis is known to be a generalist. It occurs in freshwater rivers, ponds, springs, shallow lakes with inundated marshes, mud and gravel shores of estu- aries, and oases, tolerating high temperatures and brackish conditions (Brown 1994; Plaziat \& Younis 2005; Bandel et al. 2007). As the hydrobiid Prososthe- 


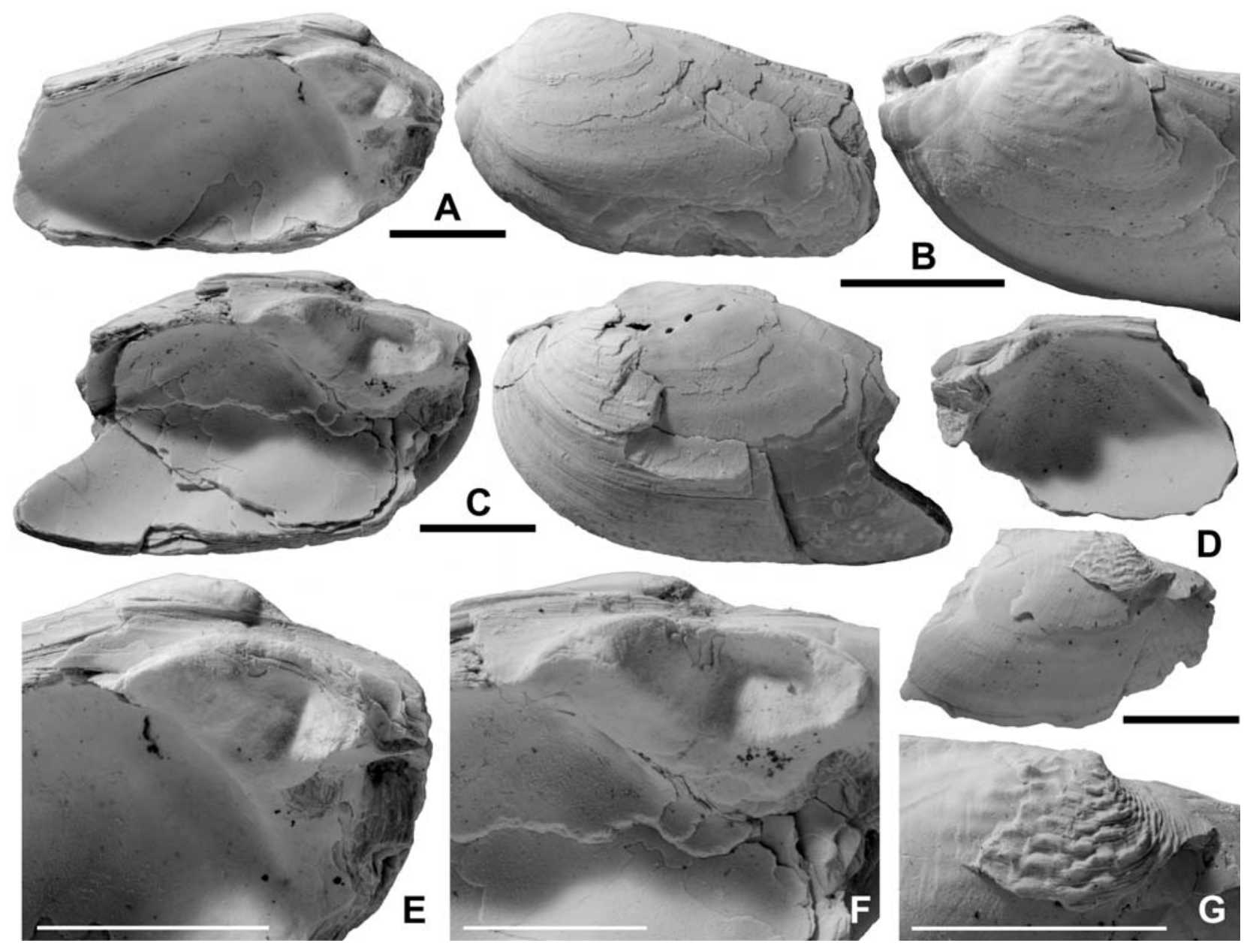

Figure 15. Unio rackianus Brusina, 1874, all specimens from sample 090713/2. A-B, E. NHMW 2011/0138/0176, LV; C, F. NHMW 2011/0138/0177, LV; D, G. NHMW 2011/0138/0162, RV. Scale bars equal $1 \mathrm{~cm}$.

nia is a fossil genus, few data on its ecologic requirements exist. Common interpretations assign it to shallow freshwater lakes and ponds with low-energy regimes (Esu \& Girotti 2001; Harzhauser et al. 2012a; Neubauer et al. 2011). Gyraulus and Radix are still present, also indicating shallow, low-energy settings. Additional pulmonate species are documented including Ferrissia and scarce Orygoceras and Planorbarius. Extant European Ferrissia wautieri is found in lentic to stagnant waters dwelling among leaves and twigs and is basically undemanding regarding water quality. Planorbarius corneus lives today in highly vegetated, standing or slowly running water bodies feeding exclusively on detritus (Glöer 2002). Herein, also the only record of the terrestrial mollusks Carychium and Verti$g o$ is documented signaling a short distance to the waterside.

At the top of Unit D1 the faunal content is strongly deviating from earlier/later intervals. The sample (not in analysis) consists of 3 taxa only, highly dominated by Bithynia and Ferrissia. Extant Bithynia tentaculata is a very adaptive and undemanding r-strategist living in stagnant and moderately running waters on detritusrich substrates (Glöer 2002). Hence, this extremely low diverse composition featuring almost exclusively highly adaptive and generally low competitive species suggests a restricted environment with adverse conditions.

In contrast, only c. $1 \mathrm{~m}$ above the second part of the Melanopsis-assemblage (Cluster 4) is characterized by a well-balanced faunal composition with about uniform distribution of abundances. Melanopsis, Prososthenia, Fossarulus, Bania, and Gyraulus all attain similar percentage values reflecting the recovering of the fauna from the preceding crisis. This is also documented by the increased morphological variability in Melanopsis; for the first time, it develops all five morphotypes, which are considered in detail in the systematic chapter. This genus is known for its morphologically highly variable species. Often, distinct morphologies are bound to certain environmental conditions. Heller \& Sivan (2002) showed strong correlation of morphotypes with flow current in Pleistocene melanopsids of the Jordan Valley. Smooth and slender forms represent agitated environments, dwelling within or in the proximity of rivers. Sculptured shells, in contrast, reflect non-turbulent habitats. Comparably, the occurrence of sculptured morphotypes in Lake Gacko coincides with the establishment of perennial open-lake conditions (Mandic et al. 
2011). Consequently, the low-energy conditions might have promoted adaptive evolution towards sculptured forms.

The following Unit D2 comprises grayish limestones signaling partial suboxic bottom conditions (Mandic et al. 2011). Coinciding with the lake-level fall and a rising oxygen level at the top of the unit a monospecific accumulation of Mytilopsis frici occurs. This pattern is similar to developments in Lake Sinj, where the massive limestone intervals, largely barren of gastropods, show abundant Mytilopsis aletici. Both taxa are interpreted to have settled in deeper, low-energy settings (Mandic et al. 2009; Neubauer et al. 2011).

Upsection, at the base of Unit E1, the diverse fauna disappears (base of the second Fossarulus-assemblage). The few and poorly preserved fossils could not be analyzed statistically, but show a return to initial compositions featuring abundant pulmonates and Fossarulus. This situation persists up to the section top.

The apparent shifts in the faunal composition, regarding occurring taxa as well as species richness, are especially evident in the nMDS (Fig. 4B) where the pulmonate/rissooid-dominated Fossarulus-assemblage and the Melanopsis-assemblage with abundant Prososthenia and Fossarulus group in separate fields. The vertical axis in the plot is thought to reflect ecological conditions. The faunal compositions of the two assemblages/groups show an ongoing trend to higher diversities and uniform distributions of abundances. The low diverse pulmonate-assemblage (G1) points to ephemeral conditions with a lentic to stagnant water body and densely vegetated watersides. The following higher diverse assemblage (G2), with taxa having broader ecological requirements, reflects the establishment of a perennial system with stable open-lake conditions and habitat diversification along the shoreface. In between, local crises occurred for short episodes, as proven by the Bithynia-Ferrissia complex in Unit D1. The third assemblage, not part of the statistical analysis, with a composition similar to the initial phase, again indicates a retreat of the lake and the return to ephemeral conditions at the lake margins. Taxa requiring stable waterbodies like Melanopsis and Prososthenia are completely missing.

The $\mathrm{x}$-axis in the plot is interpreted to mirror species richness. It correlates particularly well with the Margalef richness index (Tab. 1), computed as species richness increasing with the natural logarithm of sample size (Margalef 1958). Samples grouping to the left consist of few taxa, while samples on the right have a higher number of taxa at comparable sample size. Thus, the probability that a sample yields higher species richness at higher sample size (the "expected species richness") increases towards the right. This, in turn, fits to the interpretation above, as ephemeral habitats are expected to house few but abundant taxa, while perennial systems usually attain distinctly higher species richnesses.

\section{Conclusions}

During the Middle Miocene Climatic Optimum Lake Gacko harbored at least 17 aquatic mollusk species. Within the lake, long-term climatic oscillations are excellently reflected in changing faunal compositions, which are proven herein for the first time by means of statistical analyses. The initial as well as the final phase both signal a more arid climate resulting in a lowered lake level. At that time, assemblages typically are low diverse and consist of abundant pulmonate and rissooid gastropods. The intermediate lake high stand coincided with a more humid interval with enhanced precipitation. The mollusk fauna diversified and rissooid and melanopsid gastropods flourished, while pulmonates were only marginally present. This interpretation agrees with data of Mandic et al. (2011), who provided a more detailed classification into distinct transgression-regression cycles based on sedimentary facies and geophysical data.

All species are endemic to the DLS, two of them occur in Lake Gacko only. Also, the fauna shows variable overlap with those of other DLS lakes. This suggests that the DLS comprised a mosaic of lakes, each with a distinct species inventory with moderate overlap with neighboring lakes.

\section{Systematic paleontology}

Type material of Neumayr $(1869,1880)$, Brusina $(1870,1872,1874$, 1876, 1882, 1884, 1897, 1902, 1904) and Kochansky-Devidé \& Slišković (1978) stored in the Natural History Museum Zagreb (NHMZ), the Natural History Museum Sarajevo (NHMS) and the Geological Survey Vienna (GBA), and material from the collection of the Natural History Museum Vienna (NHMW) have been studied. Material from the present study is stored in the NHMW under the prefix 2011/0138. For further synonyms see Brusina (1907), Wenz (1923-1930) and Milan et al. (1974). Only the description for the new species is available in the print version of this paper, others appear as supplementary material.

Class Bivalvia Linnaeus, 1758

Superorder Heterodonta Neumayr, 1883

Order Venerida Gray, 1854

Family Sphaeriidae Deshayes, 1854 (1820)

\section{Pisidium Pfeiffer, 1821}

Type species. Tellina amnica Müller, 1774, Recent, Palearctic and North America.

\section{Pisidium vukovici n. sp.}

Figures $14 \mathrm{G}-\mathrm{I}$

Etymology. After Dr.sc. Boško Vuković, mine geologist of RiTE "Gacko", for his assistance and help with the geological studies in the Gacko Basin.

Holotype. Right valve illustrated in Figures 14G-I, NHMW 2011/ 0138/0173, sample 090713/2; $\mathrm{H}=2.8 \mathrm{~mm}, \mathrm{~L}=3.0 \mathrm{~mm}, \mathrm{C}=1.2 \mathrm{~mm}$. 
Paratype 1. Right valve, NHMW 2011/0138/0178, sample 090713/1. Paratype 2. Left valve, NHMW 2011/0138/0179, sample 090713/2. Paratype 3. Left valve, NHMW 2011/0138/0180, sample 090713/2.

Material. 6 single valves from samples 090713/1 (1 LV, 2 RV) and 090713/2 (2 LV, $1 \mathrm{RV}$ ) of the type horizon.

Type locality. Open-cast coal-mine "Gračanica" near Gacko, Minepit B.

Type horizon. Unit A of the Section Gračanica in Mandic et al. (2011), footwall coal II lithostratigraphic unit of the Gacko Basin, Langhian, Middle Miocene ( 15.83 Ma).

Diagnosis. Shell subtrigonal. Hinge plate massive; prominent lateral teeth.

Description. Subtriangular shell with regularly semicircular dorsal margin. Umbo low and broad, measuring $750 \mu \mathrm{m}$. In lateral view, shell roughly semilunar. Outer surface covered with faint, regular growth lines. Hinge plate prominent and broad. Ligament pit short and lanceolate. Cardinals subcentral, oblique, dipping anteriorly; C 2 broadened, blunt; C 3 prominent, crescent, convex-up, sharp, surrounded by two shallow cavities; C 4 sharp and straightened. Laterals prominent and long with bulbous, sharp cusps. On right valve anterior teeth massive, forming distinct emargination; posterior teeth somewhat weaker. In both cases inner teeth stronger than outer ones.

Remarks. This taxon can be clearly distinguished from Pisidium bellardii Brusina, 1884 by its subtrigonal shell shape and very prominent hinge plate. P. hybonatum Brusina, 1897 is somewhat broader in outline and has a less prominent hinge plate. This species, originally described from Pliocene deposits of the southern Pannonian Basin, was additionally reported by Jovanović (1935) from the close-by Bihać Basin. Shells from the possibly coeval Austrian Aflenz Basin, determined as Pisidium cf. casertanum Poli, 1791 by Harzhauser et al. (2012b), are broader and expose a narrower, delicate hinge plate. Likewise, P. amnicum (Müller, 1774) (= P. priscum Hörnes, 1862; non Eichwald, 1830) from the Middle to Late Miocene of the Central and Eastern Paratethys and the Upper Freshwater Molasse is broader and has narrower and less distinct lateral teeth (cf. Schneider \& Prieto 2011). The about coeval P. bakonyensis Kókay, 2006 from Hungary is quite similar in shape but exposes an elevated umbo and smaller lateral teeth. In shape and hinge characteristics it is similar to the Recent P. supinum Schmidt, 1851, but does not develop such a high umbo with the typical fold. Extant P. tenuilineatum Stelfox, 1918 has stronger posterior teeth and a transversally oriented C 3 .

\section{Acknowledgements}

We are grateful to the following colleagues for support: Boško Vuković and authorities of RiTE "Gacko" granted access to the mine. Jovan Olujić (Geological Survey Zvornik) introduced us to the studied localities. Stjepan Ćorić (Geological Survey Vienna) kindly provided samples from drill cores. Simon Schneider (Natural History Museum Vienna) gave helpful comments on bivalve taxonomy. Zlata Jurišić-
Polšak (Natural History Museum Zagreb), Božena Čvorović (Natural History Museum Sarajevo) and Irene Zorn (Geological Survey Vienna) made type collections accessible. Medina Mandic assisted with fossil collections in the field. Alice Schumacher (Natural History $\mathrm{Mu}-$ seum Vienna) provided macro-photographs. Finally, we are grateful to Daniela Esu (University of Rome) and Vitaliy V. Anistratenko (Schmalhausen Institute of Zoology of NAS, Ukraine) for constructive reviews and taxonomic discussion. The investigation contributes to the Austrian Science Fund projects P18519-B17 and P25365.

\section{References}

Bandel, K., Sivan, N. \& Heller, J. 2007. Melanopsis from Al-Qarn, Jordan Valley (Gastropoda: Cerithioidea). - Paläontologische Zeitschrift 81 (3): 304-315.

Brown, D. S. 1994. Freshwater Snails of Africa and their Medical Importance. Taylor \& Francis, London.

Brusina, S. 1870. Monographie der Gattungen Emmericia und Fossarulus. - Verhandlungen der kaiserlichen und königlichen zoologisch-botanischen Gesellschaft in Wien 20: 925-938.

Brusina, S. 1872. Naravoslovne crtice sa sjevero-istočne obale Jadranskoga mora. Dio prvi. Putopis. - Rad Jugoslavenske akademije znanosti i umjetnosti 19: 105-177.

Brusina, S. 1874. Fossile Binnen-Mollusken aus Dalmatien, Kroatien und Slavonien nebst einem Anhange. Actienbuchdruckerei, Agram.

Brusina, S. 1876. Decription d'espèces nouvelles, provenant des terrains tertiaires de Dalmatie. - Journal de Conchyliologie 24: $109-116$.

Brusina, S. 1882. Orygoceras. Eine neue Gasteropodengattung der Melanopsiden-Mergel Dalmatiens. - Beiträge zur Paläontologie Österreich-Ungarns und des Orients 2: 33-46.

Brusina, S. 1884. Die Neritodonta Dalmatiens und Slavoniens nebst allerlei malakologischen Bemerkungen. - Jahrbücher der Deutschen Malakozoologischen Gesellschaft 11: 17-120.

Brusina, S. 1892. Fauna fossile terziaria di Markuševec in Croazia. Con un elenco delle Dreissensidae della Dalmazia, Croazia e Slavonia. - Glasnik hrvatskog naravoslovnog društa 7: 113-210.

Brusina, S. 1897. Gragja za neogensku malakološku faunu Dalmacije, Hrvatske i Slavonije uz neke vrste iz Bosne i Hercegovine i Srbije. - Djela Jugoslavenske akademije znanosti i umjetnosti 18: $1-43$.

Brusina, S. 1902. Iconographia Molluscorum Fossilium in tellure tertiaria Hungariae, Croatiae, Slavoniae, Dalmatiae, Bosniae, Herzegovinae, Serbiae and Bulgariae inventorum. Officina Soc. Typographicae, Agram.

Brusina, S. 1904. Šipovo i njegova tercijarna fauna. - Glasnik Zemaljskog muzeja Bosne i Hercegovine 16 (4): 493-498.

Brusina, S. 1907. Naravoslovne crtice sa sjevero-istočne obale Jadranskoga mora. Dio cetvrti i posljednji. Specijalni. - Rad Jugoslavenske akademije znanosti i umjetnosti 169: 195-251.

Clarke, K. R. \& Warwick, R. M. 2001. Changes in Marine Communities: An Approach to Statistical Analysis and Interpretation. 2nd edition. Plymouth Marine Laboratory, Plymouth.

De Leeuw, A., Mandic, O., Krijgsman, W., Kuiper, K. \& Hrvatović, H. 2011. A chronostratigraphy for the Dinaride Lake System deposits of the Livno-Tomislavgrad Basin: the rise and fall of a long-lived lacustrine environment. - Stratigraphy 8 (1): 29-43.

De Leeuw, A., Mandic, O., Vranjković, A., Pavelić, D., Harzhauser, M., Krijgsman, W. \& Kuiper, K. F. 2010. Chronology and integrated stratigraphy of the Miocene Sinj Basin (Dinaride Lake System, Croatia). - Palaeogeography, Palaeoclimatology, Palaeoecology 292: 155-167.

Deshayes, G. P. 1854. Catalogue of the Conchifera or bivalve shells in the collection of the British Museum, 1-2. British Museum, London. 
Eichwald, E. 1830. Naturhistorische Skizze von Lithauen, Volhynien und Podolien in geognostisch-mineralogischer, botanischer und zoologischer Hinsicht. Leipzig (published by author).

Esu, D. \& Girotti, O. 2001. The genus Prososthenia Neumayr in Italy (Gastropoda: Prosobranchia: Hydrobiidae). - Bollettino della Società Paleontologica Italiana 40 (2): 179-184.

Glöer, P. 2002. Die Tierwelt Deutschlands, 73. Teil: Die Süßwassergastropoden Nord- und Mitteleuropas. Bestimmungsschlüssel, Lebensweise, Verbreitung. ConchBooks, Hackenheim.

Gray, J. E. 1854. A revision of the arrangement of the families of bivalve shells (Conchifera). - Annals and Magazine of Natural History (series 2) 13 (77): 408-418.

Hammer, Ø., Harper, D. A. T. \& Ryan, P. D. 2001. Past: Paleontological Statistics Software Package for Education and Data Analysis. - Palaeontologia Electronica 4: 1-9.

Harzhauser, M. \& Mandic, O. 2008. Neogene lake systems of Central and South-Eastern Europe: Faunal diversity, gradients and interrelations. - Palaeogeography, Palaeoclimatology, Palaeoecology 260: 417-434.

Harzhauser, M. \& Mandic, O. 2010. Neogene dreissenids in Central Europe: evolutionary shifts and diversity changes. In van der Velde, G., Rajagopal, S. \& bij de Vaate, A. (eds). The Zebra Mussel in Europe. Backhuys Publishers, Leiden/Margraf Publishers, Weikersheim: pp. 11-29.

Harzhauser, M., Mandic, O., Latal, C. \& Kern, A. 2012a. Stable isotope composition of the Miocene Dinaride Lake System deduced from its endemic mollusc fauna. - Hydrobiologia 682: 27-46.

Harzhauser, M., Neubauer, T. A., Mandic, O., Zuschin, M. \& Ćorić, S. 2012b. A Middle Miocene endemic freshwater mollusc assemblage from an intramontane Alpine lake (Aflenz Basin, Eastern Alps, Austria). - Paläontologische Zeitschrift 86 (1): 23-41.

Harzhauser, M. \& Piller, W. E. 2007. Benchmark data of a changing sea. - Palaeogeography, Palaeobiogeography and Events in the Central Paratethys during the Miocene. - Palaeogeography, Palaeoclimatology, Palaeoecology 253: 8-31.

Heller, J. \& Sivan, N. 2002. Melanopsis from the Pleistocene site of 'Ubeidiya, Jordan Valley: direct evidence of early hybridization (Gastropoda: Cerithioidea). - Biological Journal of the Linnean Society 75: 39-57.

Hörnes, M. 1859-1867. Die fossilen Mollusken des Tertiär-Beckens von Wien. II. Bivalven. - Abhandlungen der Geologischen Reichsanstalt 4: 1-430 [1-116 (1859); 117-214 (1862); 215-342 (1965); 343-430 (1867)].

Hrvatović, H. 2006. Geological Guidebook through Bosnia and Herzegovina. Geological Survey of Federation BiH, Sarajevo.

Jovanović, R. N. 1935. Prilog fauni Bihackog tercijarnog bazena. Vesnik geoloskog instituta kraljevine Jugoslavije 4: 157-176.

Kochansky-Devidé, V. \& Slišković, T. 1978. Miocenske kongerije Hrvatske, Bosne i Hercegovine. - Palaeontologia jugoslavica 19: $1-98$.

Krstić, N., Olujić, J., Đajić, S., Đorđević-Milutinović, D. \& Tanasković, L. 2009. Fossils from the drill hole GS-1 near Gacko, SE Dinaric Alps. - Bulletin of the Natural History Museum 2: 35-61.

Krstić, N., Savić, L., Jovanović, G. \& Bodor, E. 2003. Lower Miocene lakes of the Balkan Land. - Acta Geologica Hungarica 46: 291299.

Kókay, J. 2006. Nonmarine mollusc fauna from the Lower and Middle Miocene, Bakony Mts., W Hungary. - Geologica Hungarica, Series Palaeontologica 56: 1-196.

Linnaeus, C. 1758. Systema naturae per regna tria naturae, secundum classes, ordines, genera, species, cum characteribus, differentiis, synonymis locis. Tomus 1. Laurentius Salvius, Holmiae.

Mandic, O., De Leeuw, A., Vuković, B., Krijgsman, W., Harzhauser, M. \& Kuiper, K. F. 2011. Palaeoenvironmental evolution of Lake
Gacko (Southern Bosnia and Herzegovina): Impact of the Middle Miocene Climatic Optimum on the Dinaride Lake System. - Palaeogeography, Palaeoclimatology, Palaeoecology 299: 475-492.

Mandic, O., Pavelić, D., Harzhauser, M., Zupanič, J., Reischenbacher, D., Sachsenhofer, R. F., Tadej, N. \& Vranjković, A. 2009. Depositional history of the Miocene Lake Sinj (Dinaride Lake System, Croatia): a long-lived hard-water lake in a pull-apart tectonic setting. - Journal of Paleolimnology 41: 431-452.

Margalef, R. 1958. Information theory in ecology. - General systematics 3: $1-10$.

Milan, A., Sakač, K. \& Žagar-Sakač, A. 1974. Katalog originala tipova vrsta pohranjenih u Geološko-paleontološkom muzeju u Zagrebu. Geološko-paleontološki muzej u Zagrebu, Zagreb.

Milojević, R. 1966. Korelacioni i neki ekonomsko-geološki elementi razvoja ugljenonosne serije Gatačkog bazena. - Geološki glasnik 11: $355-370$

Milojević, R. 1976. Mineralne sirovine Bosne i Hercegovine. Prvi tom. Ležišta uglja. Ležišta nemetala. Geoinžinjering, Sarajevo.

Mirković, M., Kalezić, M., Pajović, M., Rašković, S., Cepić, M. \& Vujisić, P. 1974. Gacko. Osnovna geološka karta 1:100 000. Savezni geološki zavod, Beograd.

Mojićević, M. \& Laušević, M. 1965. Nevesinje. Osnovna geološka karta 1:100 000. Savezni geološki zavod, Beograd.

Müller, O. F. 1773-1774. Vermium terrestrium et fluviatilium historia, seu animalium Infusoriorum, Helminthicorum et Testaceorum non marinorum succincta historia. Heineck \& Faber, Havniae et Lipsiae.

Neubauer, T. A., Mandic, O. \& Harzhauser, M. 2011. Middle Miocene Freshwater Mollusks from Lake Sinj (Dinaride Lake System, SE Croatia; Langhian). - Archiv für Molluskenkunde 140 (2): 201237.

Neubauer, T. A., Mandic, O., Harzhauser, M. \& Hrvatović, H. 2012 in press. A new Miocene lacustrine mollusc fauna of the Dinaride Lake System and its palaeobiogeographic, palaeoecologic, and taxonomic implications. - Palaeontology.

Neumayr, M. 1869. II. Beiträge zur Kenntniss fossiler Binnenfaunen. - Jahrbuch der kaiserlichen und königlichen geologischen Reichsanstalt 19: 355-382.

Neumayr, M. 1880. V. Tertiäre Binnenmollusken aus Bosnien und der Hercegovina. - Jahrbuch der kaiserlichen und königlichen geologischen Reichsanstalt 30 (2): 463-486.

Pfeiffer, C. 1821. Naturgeschichte deutscher Land- und SüsswasserMollusken. Erste Abtheilung. Landes-Industrie-Comptoir, Weimar

Plaziat, J.-C. \& Younis, W. R. 2005. The modern environments of Molluscs in southern Mesopotamia, Iraq: A guide to paleogeographical reconstructions of Quaternary fluvial, palustrine and marine deposits. - Carnets de Géologie/Notebooks on Geology, Article 2005/01 (CG2005_A01)

Poli, J. X. 1791. Testacea utriusque Siciliae eorumque historia et anatome tabulis aeneis illustrata. Tomus primus. Regio Typographeio, Parmae.

Rögl, F. 1998. Paleogeographic considerations for Mediterranean and Paratethys seaways (Oligocene to Miocene). - Annalen des Naturhistorischen Museums in Wien 99A: 279-310.

Schmidt, A. 1851. Malakologische Mittheilungen. - Zeitschrift für Malakozoologie 7 (8): 113-120.

Schneider, S. \& Prieto, J. 2011. First record of an autochthonous community of fluviatile freshwater molluscs from the Middle/Late Miocene Upper Freshwater Molasse (southern Germany). - Archiv für Molluskenkunde 140 (1): 1-18.

Stelfox, A. W. 1918. The Pisidium fauna of the Grand Junction Canal in Herts. and Bucks. - Journal of Conchology 15 (10): 289-304.

Wenz, W. 1923-1930. Fossilium Catalogus I: Animalia. Gastropoda extramarina tertiaria. W. Junk, Berlin. 


\section{Appendix}

Table 1. Simper analysis, using Bray-Curtis distances and a cut-off level for low contributions of 90\%. Additionally, data on Margalef's richness index are included.

\begin{tabular}{llll}
\hline & Groups & Clusters & Margalef index \\
\hline 0708/GA1 & 1 & 1 & 0.456 \\
\hline 0907/Moll2 & 1 & 1 & 0.858 \\
\hline 0907/Moll1 & 1 & 2 & 1.077 \\
090713/1 & 1 & 2 & 1.507 \\
090713/2 & 1 & 2 & 1.447 \\
0804-039 & 2 & 3 & 1.719 \\
0804-039 coal & 2 & 3 & 1.853 \\
0804-039b & 2 & 3 & 2.212 \\
0907/Moll4 & 2 & 4 & 1.580 \\
0907/Moll4A & 2 & 4 & 1.514 \\
\hline
\end{tabular}

Groups

Group 1 - Average similarity: $71.69 \%$

\begin{tabular}{llllll}
\hline Species & Av. Abund & Av. Sim & Sim/SD & Contrib \% & Cum. \% \\
\hline Gyraulus pulici & 6.66 & 27.28 & 2.80 & 38.05 & 38.05 \\
Bania valvatoides & 4.57 & 18.28 & 6.08 & 25.50 & 63.55 \\
Fossarulus moniliferus & 3.60 & 14.49 & 6.17 & 20.21 & 83.76 \\
Radix korlevici & 2.92 & 8.04 & 1.14 & 11.21 & 94.97 \\
\hline
\end{tabular}

Group 2 - Average similarity: $70.05 \%$

\begin{tabular}{llcccc}
\hline Species & Av. Abund & Av. Sim & Sim/SD & Contrib \% & Cum. \% \\
\hline Prososthenia neutra & 5.27 & 18.77 & 14.82 & 26.80 & 26.80 \\
Fossarulus moniliferus & 5.00 & 16.18 & 2.86 & 23.10 & 49.90 \\
Melanopsis lyrata & 3.87 & 11.76 & 2.92 & 16.79 & 66.69 \\
Gyraulus pulici & 2.65 & 7.36 & 3.16 & 10.50 & 77.19 \\
Radix korlevici & 2.07 & 5.99 & 2.33 & 8.55 & 85.74 \\
Bania valvatoides & 2.04 & 3.14 & 0.62 & 4.48 & 90.23 \\
\hline
\end{tabular}

Groups 1 \& 2 - Average dissimilarity: $53.56 \%$

\begin{tabular}{lllllll}
\hline Species & $\begin{array}{l}\text { Group 1 } \\
\text { Av. Abund }\end{array}$ & $\begin{array}{l}\text { Group } 2 \\
\text { Av. Abund }\end{array}$ & Av. Diss & Diss/SD & Contrib \% & Cum. \% \\
\hline Prososthenia neutra & 1.06 & 5.27 & 9.23 & 3.00 & 17.23 & 17.23 \\
Gyraulus pulici & 6.66 & 2.65 & 9.00 & 1.68 & 16.81 & 34.04 \\
Melanopsis lyrata & 0.00 & 3.87 & 8.39 & 2.96 & 15.66 & 49.70 \\
Bania valvatoides & 4.57 & 2.04 & 5.81 & 1.51 & 10.85 & 60.55 \\
Fossarulus moniliferus & 3.60 & 5.00 & 4.03 & 1.66 & 7.53 & 68.08 \\
Radix korlevici & 2.92 & 2.07 & 3.70 & 1.63 & 6.92 & 75.00 \\
Ferrissia illyrica & 0.00 & 1.34 & 2.85 & 1.06 & 5.33 & 80.32 \\
Unio rackianus & 0.92 & 0.00 & 1.79 & 0.80 & 3.34 & 83.67 \\
Mytilopsis jadrovi & 0.00 & 0.71 & 1.56 & 0.79 & 2.91 & 86.58 \\
Orygoceras dentaliforme & 0.00 & 0.72 & 1.53 & 1.17 & 2.86 & 89.44 \\
Pisidium bellardii & 0.45 & 0.91 & 1.53 & 1.26 & 2.85 & 92.29 \\
\hline
\end{tabular}


Table 1. Continued

Clusters

Cluster 1 - Average similarity: $81.67 \%$

\begin{tabular}{lllllc}
\hline Species & Av. Abund & Av. Sim & Sim/SD & Contrib \% & Cum. \% \\
\hline Gyraulus pulici & 8.60 & 48.49 & $* * *$ & 59.38 & 59.38 \\
Bania valvatoides & 3.43 & 17.98 & $* * *$ & 22.02 & 81.39 \\
Fossarulus moniliferus & 3.20 & 15.20 & $* * *$ & 18.61 & 100.00 \\
\hline
\end{tabular}

Cluster 2 - Average similarity: $81.29 \%$

\begin{tabular}{lccccc}
\hline Species & Av. Abund & Av. Sim & Sim/SD & Contrib \% & Cum. \% \\
\hline Bania valvatoides & 5.33 & 20.70 & 5.02 & 25.46 & 25.46 \\
Gyraulus pulici & 5.38 & 20.16 & 15.42 & 24.80 & 50.26 \\
Radix korlevici & 4.05 & 14.96 & 20.91 & 18.40 & 68.66 \\
Fossarulus moniliferus & 3.86 & 13.46 & 4.99 & 16.56 & 85.23 \\
Prososthenia neutra & 1.77 & 6.16 & 9.13 & 7.58 & 92.81 \\
\hline
\end{tabular}

Cluster 3 - Average similarity: $79.17 \%$

\begin{tabular}{lccccc}
\hline Species & Av. Abund & Av. Sim & Sim/SD & Contrib \% & Cum. \% \\
\hline Fossarulus moniliferus & 5.81 & 21.37 & 63.54 & 26.99 & 26.99 \\
Prososthenia neutra & 5.63 & 19.96 & 10.13 & 25.21 & 52.20 \\
Radix korlevici & 2.66 & 9.55 & 10.86 & 12.06 & 64.26 \\
Melanopsis lyrata & 3.06 & 9.34 & 2.75 & 11.80 & 76.06 \\
Ferrissia illyrica & 2.23 & 6.42 & 21.22 & 8.11 & 84.16 \\
Gyraulus pulici & 1.96 & 5.80 & 15.25 & 7.33 & 91.49 \\
\hline
\end{tabular}

Cluster 4 - Average similarity: $83.60 \%$

\begin{tabular}{llcccc}
\hline Species & Av. Abund & Av. Sim & Sim/SD & Contrib \% & Cum. \% \\
\hline Melanopsis lyrata & 5.10 & 18.70 & $* * *$ & 22.37 & 22.37 \\
Prososthenia neutra & 4.73 & 18.44 & $* * *$ & 22.06 & 44.43 \\
Bania valvatoides & 3.80 & 11.64 & $* * *$ & 13.92 & 58.35 \\
Gyraulus pulici & 3.69 & 10.97 & $* * *$ & 13.12 & 71.47 \\
Fossarulus moniliferus & 3.78 & 9.86 & $* * *$ & 11.79 & 83.26 \\
Mytilopsis jadrovi & 1.79 & 6.23 & $* * *$ & 7.46 & 90.72 \\
\hline
\end{tabular}


Table 1. Continued

Clusters 1 \& 2 - Average dissimilarity: $34.78 \%$

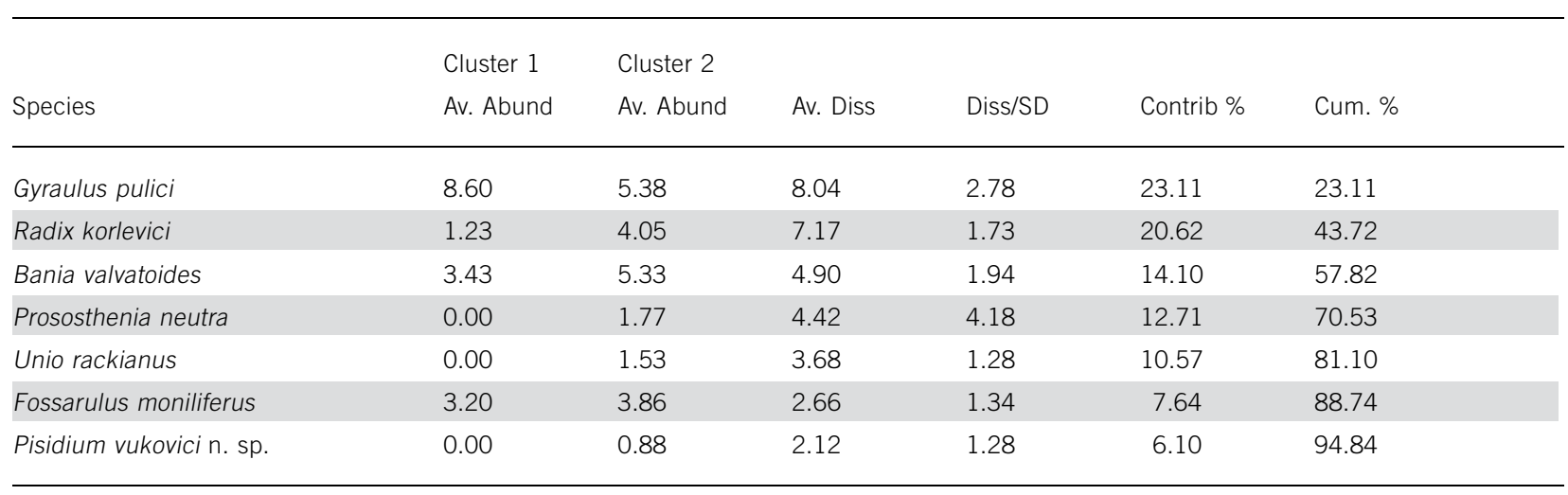

Clusters $1 \& 3$ - Average dissimilarity: $66.56 \%$

\begin{tabular}{|c|c|c|c|c|c|c|}
\hline & Cluster 1 & Cluster 3 & & & & \\
\hline Species & Av. Abund & Av. Abund & Av. Diss & Diss/SD & Contrib \% & Cum. \% \\
\hline Gyraulus pulici & 8.60 & 1.96 & 15.62 & 5.61 & 23.47 & 23.47 \\
\hline Prososthenia neutra & 0.00 & 5.63 & 13.19 & 8.83 & 19.82 & 43.30 \\
\hline Melanopsis lyrata & 0.00 & 3.06 & 7.17 & 3.43 & 10.78 & 54.07 \\
\hline Fossarulus moniliferus & 3.20 & 5.81 & 6.19 & 2.91 & 9.30 & 63.37 \\
\hline Bania valvatoides & 3.43 & 0.86 & 5.98 & 1.82 & 8.98 & 72.35 \\
\hline Ferrissia illyrica & 0.00 & 2.23 & 5.20 & 2.87 & 7.81 & 80.16 \\
\hline Radix korlevici & 1.23 & 2.66 & 3.52 & 1.07 & 5.29 & 85.45 \\
\hline Orygoceras dentaliforme & 0.00 & 1.19 & 2.79 & 7.53 & 4.19 & 89.65 \\
\hline Mytilopsis sp. & 0.00 & 0.89 & 2.10 & 1.20 & 3.16 & 92.81 \\
\hline
\end{tabular}

Clusters 2 \& 3 - Average dissimilarity: $53.76 \%$

\begin{tabular}{|c|c|c|c|c|c|c|}
\hline & Cluster 2 & Cluster 3 & & & & \\
\hline Species & Av. Abund & Av. Abund & Av. Diss & Diss/SD & Contrib \% & Cum. \% \\
\hline Bania valvatoides & 5.33 & 0.86 & 9.04 & 2.87 & 16.81 & 16.81 \\
\hline Prososthenia neutra & 1.77 & 5.63 & 7.78 & 5.02 & 14.48 & 31.29 \\
\hline Gyraulus pulici & 5.38 & 1.96 & 6.96 & 2.65 & 12.95 & 44.24 \\
\hline Melanopsis lyrata & 0.00 & 3.06 & 6.15 & 3.53 & 11.45 & 55.69 \\
\hline Ferrissia illyrica & 0.00 & 2.23 & 4.46 & 2.95 & 8.30 & 63.99 \\
\hline Fossarulus moniliferus & 3.86 & 5.81 & 3.99 & 1.90 & 7.43 & 71.42 \\
\hline Unio rackianus & 1.53 & 0.00 & 2.97 & 1.33 & 5.52 & 76.93 \\
\hline Radix korlevici & 4.05 & 2.66 & 2.76 & 1.79 & 5.13 & 82.06 \\
\hline Orygoceras dentaliforme & 0.00 & 1.19 & 2.40 & 7.58 & 4.46 & 86.52 \\
\hline Mytilopsis sp. & 0.00 & 0.89 & 1.80 & 1.23 & 3.36 & 89.87 \\
\hline Pisidium vukovici n. sp. & 0.88 & 0.00 & 1.71 & 1.33 & 3.18 & 93.06 \\
\hline
\end{tabular}


Table 1. Continued

Clusters 1 \& 4 - Average dissimilarity: $51.00 \%$

\begin{tabular}{lllllll}
\hline Species & $\begin{array}{l}\text { Cluster } 1 \\
\text { Av. Abund }\end{array}$ & $\begin{array}{l}\text { Cluster } 4 \\
\text { Av. Abund }\end{array}$ & Av. Diss & Diss/SD & Contrib \% & Cum. \% \\
\hline Melanopsis lyrata & 0.00 & 5.10 & 12.18 & 9.82 & 23.88 & 23.88 \\
Gyraulus pulici & 8.60 & 3.69 & 11.82 & 3.39 & 23.17 & 47.06 \\
Prososthenia neutra & 0.00 & 4.73 & 11.29 & 18.83 & 22.13 & 69.18 \\
Mytilopsis jadrovi & 0.00 & 1.79 & 4.27 & 6.68 & 8.37 & 77.55 \\
Fossarulus moniliferus & 3.20 & 3.78 & 3.06 & 1.17 & 6.01 & 83.56 \\
Radix korlevici & 1.23 & 1.18 & 2.93 & 5.50 & 5.75 & 89.31 \\
Pisidium bellardii & 0.00 & 1.06 & 2.52 & 13.20 & 4.95 & 94.26 \\
\hline
\end{tabular}

Clusters 2 \& 4 - Average dissimilarity: $41.97 \%$

\begin{tabular}{lllllll}
\hline Species & $\begin{array}{l}\text { Cluster 2 } \\
\text { Av. Abund }\end{array}$ & $\begin{array}{l}\text { Cluster } 4 \\
\text { Av. Abund }\end{array}$ & Av. Diss & Diss/SD & Contrib \% & Cum. \% \\
\hline Melanopsis lyrata & 0.00 & 5.10 & 10.42 & 10.10 & 24.84 & 24.84 \\
Prososthenia neutra & 1.77 & 4.73 & 6.06 & 5.49 & 14.45 & 39.29 \\
Radix korlevici & 4.05 & 1.18 & 5.82 & 3.69 & 13.88 & 53.16 \\
Mytilopsis jadrovi & 0.00 & 1.79 & 3.65 & 7.00 & 8.70 & 61.87 \\
Gyraulus pulici & 5.38 & 3.69 & 3.56 & 1.18 & 8.49 & 70.36 \\
Bania valvatoides & 5.33 & 3.80 & 3.34 & 1.52 & 7.97 & 78.32 \\
Unio rackianus & 1.53 & 0.00 & 3.01 & 1.29 & 7.18 & 85.50 \\
Fossarulus moniliferus & 3.86 & 3.78 & 2.59 & 1.32 & 6.17 & 91.67 \\
\hline
\end{tabular}

Clusters $3 \& 4$ - Average dissimilarity: $36.77 \%$

\begin{tabular}{lllllll}
\hline Species & $\begin{array}{l}\text { Cluster 3 } \\
\text { Av. Abund }\end{array}$ & $\begin{array}{l}\text { Cluster } 4 \\
\text { Av. Abund }\end{array}$ & Av. Diss & Diss/SD & Contrib \% & Cum. \% \\
\hline Bania valvatoides & 0.86 & 3.80 & 5.67 & 1.83 & 15.43 & 15.43 \\
Ferrissia illyrica & 2.23 & 0.00 & 4.28 & 2.88 & 11.65 & 27.08 \\
Melanopsis lyrata & 3.06 & 5.10 & 3.93 & 2.19 & 10.70 & 37.78 \\
Fossarulus moniliferus & 5.81 & 3.78 & 3.88 & 1.46 & 10.57 & 48.35 \\
Mytilopsis jadrovi & 0.00 & 1.79 & 3.45 & 7.59 & 9.38 & 57.73 \\
Gyraulus pulici & 1.96 & 3.69 & 3.32 & 1.51 & 9.04 & 66.76 \\
Radix korlevici & 2.66 & 1.18 & 2.85 & 4.63 & 7.76 & 74.52 \\
Orygoceras dentaliforme & 1.19 & 0.00 & 2.30 & 7.94 & 6.25 & 80.77 \\
Prososthenia neutra & 5.63 & 4.73 & 1.75 & 1.70 & 4.75 & 85.53 \\
Mytilopsis sp. & 0.89 & 0.00 & 1.73 & 1.20 & 4.71 & 90.23 \\
\hline
\end{tabular}

